\title{
Influence of Soil Temperature and Matric Potential on Sugar Beet Seedling Colonization and Suppression of Pythium Damping-Off by the Antagonistic Bacteria Pseudomonas fluorescens and Bacillus subtilis
}

\author{
C. S. Schmidt, F. Agostini, C. Leifert, K. Killham, and C. E. Mullins
}

First author: University of Aberdeen, Department of Molecular and Cell Biology, IMS Foresterhill, Aberdeen AB25 2ZD, UK; second author: ADAS Wolverhampton, Wergs Road, Wolverhampton WV6 8QT, UK; third author: University of Newcastle upon Tyne, Tesco Centre for Organic Agriculture, Nafferton Farm, Stocksfield, Northumberland NE43 7XD, UK; and fourth and fifth authors: University of Aberdeen, Department of Plant and Soil Science, Cruickshank Building, St Machar Drive, Aberdeen AB24 3UU, UK.

Accepted for publication 26 November 2003.

\begin{abstract}
Schmidt, C. S., Agostini, F., Leifert, C., Killham, K., and Mullins, C. E. 2004. Influence of soil temperature and matric potential on sugar beet seedling colonization and suppression of Pythium damping-off by the antagonistic bacteria Pseudomonas fluorescens and Bacillus subtilis. Phytopathology 94:351-363.

Pseudomonas fluorescens B5 and Bacillus subtilis MBI 600 colonized sugar beet seedlings at matric potentials of $-7 \times 10^{3},-140 \times 10^{3}$, and $-330 \times 10^{3} \mathrm{~Pa}$ and under five temperature regimes ranging from 7 to $35^{\circ} \mathrm{C}$, with diurnal fluctuations of 5 to $22^{\circ} \mathrm{C}$. No interaction between matric potential and temperature was observed. In situ bioluminescence indicated physiological activity of Pseudomonas fluorescens B5. Colonization of the root at $\geq 4 \mathrm{~cm}$ below the seed decreased at very low matric potential $\left(-330 \times 10^{3} \mathrm{~Pa}\right)$. Total population size of Pseudomonas fluorescens B5 per seedling was significantly increased at $-140 \times 10^{3} \mathrm{~Pa}$. However, matric potential had no significant effect on the population density of Pseudomonas fluorescens per gram of root fresh weight and did not affect the distribution of the population down the root. Total population size per seedling and downward colonization by Pseudomonas fluorescens B5 were significantly reduced at high temperatures (25 to

sphere populations of Pseudomonas fluorescens B5. Populations of $B$. subtilis MBI 600, which consisted largely of spores, were slightly reduced at lower matric potentials and were not affected by temperature. Survival and dry weight of plants in soils infested with Pythium spp. decreased with increasing soil temperature and matric potential, indicating an increase in disease pressure. However, there was no significant interaction between the two factors. At $-330 \times 10^{3} \mathrm{~Pa}$, soil dryness but not Pythium infection was the limiting factor for plant emergence. At temperatures of 7 to $25^{\circ} \mathrm{C}$ and matric potentials of $-7 \times 10^{3}$ to $-120 \times 10^{3} \mathrm{~Pa}$, treatment with Pseudomonas fluorescens B5 increased plant survival and dry weight. At $7^{\circ} \mathrm{C}$ and $-120 \times 10^{3} \mathrm{~Pa}$, there was almost complete emergence of seeds treated with Pseudomonas fluorescens B5. Antagonistic activity of Pseudomonas fluorescens B5 decreased with increasing soil temperature and decreasing matric potential. At 25 to $35^{\circ} \mathrm{C}$ and $-7 \times$ $10^{3} \mathrm{~Pa}$, no effect was observed. In regimes with different day and night temperatures, the maximum (day) temperature was decisive for disease development and antagonistic activity. B. subtilis MBI 600 displayed no significant antagonistic effect against Pythium ultimum and did not influence the performance of Pseudomonas fluorescens B5 in combined inocula.
\end{abstract} $35^{\circ} \mathrm{C}$ ). Maximum colonization down the root occurred at intermediate temperature $\left(15^{\circ} \mathrm{C}\right)$ at both matric potentials $\left(-7 \times 10^{3}\right.$ and $\left.-140 \times 10^{3} \mathrm{~Pa}\right)$. Addition of $B$. subtilis MBI 600 to the seed had no effect on rhizo-
Additional keywords: lux-marking, root colonization, soilborne diseases.
Pythium ultimum is the most significant causal agent of damping-off (34). It is currently controlled by the incorporation of fungicides in the seed pellet. However, the use of seedborne biocontrol agents against soilborne diseases is a particularly promising alternative to fungicides. Because sugar beet has to be pelleted to permit mechanical sowing, biocontrol agents can easily be added in substantial numbers to the seed pellet. On soil, microorganisms encounter a more protected and less hostile environment than on aerial plant surfaces (11). Nevertheless, reliable control of soilborne pathogens under field conditions has rarely been achieved $(7,50,56)$, and few biocontrol agents have found their way into commercial practice, despite many published studies.

The main reasons for the variability of biocontrol performance in the field are varying environmental conditions (59), which

Corresponding author: C. Leifert; E-mail address: c.leifert@ncl.ac.uk

Publication no. P-2004-0210-01R

(c) 2004 The American Phytopathological Society affect survival, activity, and antibiotic production of biocontrol inoculants. The two most significant parameters influencing the survival of bacteria in soil are temperature $(48,52)$ and matric potential $(37,41)$. Soil matric potential is probably the most relevant moisture parameter for soil bacteria. In three contrasting soils, rhizosphere populations were similar at the same matric potential, although the gravimetric water content and percent water saturation differed widely (23). Mathre et al. (35) found that soil matric potential and temperature were the most important factors for colonization of the surface of maize seeds and biological control of Pythium spp. by pseudomonads, but they did not study the interaction between these factors. Their colonization assessment focused on the seed surface, which is an important entry site for early infections that cause pre-emergence damping-off $(14,15)$. To date, no comparable study on matric potential and temperature exists for sugar beet.

The introduction of lux genes into bacterial strains and measurement of the resulting bioluminescence provides a sensitive marker to track introduced rhizobacteria in nonsterile soil environments 
and to estimate physiological activity in situ $(25,60)$. Bioluminescence responds even more readily to changes in the physiological status (38) than dehydrogenase activity and thus represents physiological activity more accurately. lux-marked strains have also been used to investigate the effects of soil matric potential (37) and soil temperature (48). Physiological activity in situ (i.e., at the entry sites of the pathogen) is considered a necessary prerequisite for successful biological control (60), but comparative investigations of root colonization, activity, and biocontrol efficacy have not been made although they are of crucial importance to assess the relevance of in situ colonization and activity for biological control.

Combinations of biocontrol strains have been shown to be superior to single inocula in a number of cases $(10,45)$. Mixtures of strains may exert biological control under a broader range of conditions, because strains with different ecological optima may complement each other. This is thought to be the reason for the improved biocontrol efficacy of mixed strains in the field. However, the environmental profile of a mixed inoculum has not yet been compared with that of its single components to test these assumptions.

In this study, the following hypotheses were tested: (i) Soil temperature, diurnal temperature fluctuation, and matric potential affect root colonization of the bacterial antagonists Pseudomonas fluorescens B5 and Bacillus subtilis MBI 600 and their biocontrol activity toward Pythium ultimum. (ii) Maximum biocontrol activity occurs only under optimal conditions. (iii) There is an interaction between the effects of matric potential and soil temperature on biocontrol activity and root colonization. (iv) Root colonization and in situ bioluminescence are predictors for biocontrol activity. (v) Combined inocula result in better biological control under a broader range of conditions. (vi) Application in a combined inoculum influences root colonization by the individual antagonists. To test these hypotheses, we investigated the effects of soil temperature and the amplitude of diurnal soil temperature fluctuation on colonization of infection sites (roots and hypocotyl of sugar beet seedlings) and on antagonistic activity against Pythium ultimum by the biocontrol strains Pseudomonas fluorescens B5 and B. subtilis MBI 600. Secondly, we investigated the combined effects of soil matric potential and temperature on these factors. In all experiments, single strain inocula and combined inocula were compared.

\section{MATERIALS AND METHODS}

Experimental design. Two separate sets of experiments on sugar beet seedlings were conducted to meet the three objectives of this work. In both of these, root colonization and biocontrol activity against Pythium ultimum were determined. In the first set of experiments, the effects of five soil temperature regimes with different day and night temperatures on root colonization, and seedling survival in soil at a constant matric potential (nominally $-10 \times 10^{3} \mathrm{~Pa}$ ) were compared. In the second set of experiments, the effects of three matric potentials $\left(-7 \times 10^{3},-140 \times 10^{3}\right.$, and $\left.-330 \times 10^{3} \mathrm{~Pa}\right)$ on colonization and biocontrol activity at three constant soil temperatures $\left(7,15\right.$, and $\left.25^{\circ} \mathrm{C}\right)$ were compared. Because there was very limited seed emergence at $-330 \times$ $10^{3} \mathrm{~Pa}$, this treatment was only performed at $15^{\circ} \mathrm{C}$. Three replicates were included per treatment. Although the experiments as a whole were not repeated, the repetition of selected treatments $\left(15^{\circ} \mathrm{C},-10 \times 10^{3} \mathrm{~Pa}\right)$ showed excellent reproducibility of the results. Furthermore, the factorial design of the experiments provided additional internal repetition and the main factor effects were reproduced under a wide range of variation of the other factors.

Strains and seeds used. Pseudomonas fluorescens B5 (21) was obtained from the research group of G. A. Wolf, Institute of Plant Pathology and Plant Protection, University of Göttingen, Ger- many. The Pythium ultimum isolate was obtained from the Department of Plant and Soil Science, University of Aberdeen. B. subtilis MBI 600 (13) was obtained from Microbio Ltd., Hempstead, UK (now Becker Underwood, West Sussex, UK). For root colonization studies, lux genes from Vibrio fischerii were introduced into the bacterial strains. Pseudomonas fluorescens B5 was chromosomally marked using mini-transposon Tn5 with a lux $\mathrm{AB}$ gene cassette and a tetracycline resistance gene (strain B5L9) according to the protocol described by De Lorenzo et al. (9). B. subtilis MBI 600 was marked with plasmid pSB340 containing a lux $\mathrm{AB}$ gene fusion cassette and chloramphenicol and erythromycin resistance genes as described by Knox et al. (29). The luxmarked derivatives did not differ in their in vitro growth characteristics from their wild-type parent strains. In in vitro cultures, bioluminescence was significantly correlated with dehydrogenase activity and cell density $(28,29,49)$. Thus, bioluminescence was a true indicator of physiological activity $(26,60)$. However, lux marking negatively affected biocontrol activity of $B$. subtilis MBI 600 (29). Therefore, the wild-type strains of both antagonists were used in assays on biocontrol activity. Unpelleted sugar beet seeds (Beta vulgaris L.) of cv. Samantha and commercial seed pelleting substances were obtained from KWS SAAT AG, Einbeck, Germany; seed pelleting was performed as described below.

Microcosm set-up. Microcosms consisted of PVC columns ( $7 \times 7 \mathrm{~cm}^{2}$; electric cable conduit) $29.8 \mathrm{~cm}$ high with a Perspex plate fitted at the base. One side was removable to allow easier root recovery. The soil column height was $25 \mathrm{~cm}$. A layer of gravel (1-cm-thick) was packed at the bottom of each microcosm to facilitate drainage and soil aeration. Sandy loam topsoil (Craibstone, Scotland) was air-dried for storage and sieved $(<3.25 \mathrm{~mm})$; before use, the gravimetric water content was adjusted by spraying consecutive 2-cm-thick layers of soil evenly with water on a balance. The soil was then covered with plastic sheeting, allowed to equilibrate overnight, and mixed. The relationship between water content and matric potential is subject to hysteresis (i.e., it is not reversible) (33). Therefore, to avoid potentially large hysteresis errors, the water contents of 0.32 , 0.20 , and $0.13 \mathrm{~g}$ per $\mathrm{g}$ of soil required to obtain target matric potentials of $-10 \times 10^{3},-100 \times 10^{3}$, and $-300 \times 10^{3} \mathrm{~Pa}$, respectively, were determined from a wetting curve. This was determined by wetting the soil to a range of water contents and measuring its water potential with a thermocouple psychrometer (Model SC-10; Decagon Devices, Pullman, WA). Soil was packed in the microcosms to a bulk density of $1.0 \mathrm{~g} \mathrm{~cm}^{-3}$. A uniform bulk density was achieved by packing the required quantity of soil in four 4-cm-thick layers, one 3-cm-thick layer, and one 2-cm-thick layer. In assays on antagonistic activity against Pythium ultimum, but not in assays on bacterial root colonization, inoculum of Pythium ultimum was added to the top $9 \mathrm{~cm}$ of soil as described below. Per microcosm, 16 sugar beet seeds were sown at a soil depth of $2 \mathrm{~cm}$. The soil surface was then covered with a $2-\mathrm{cm}$ layer $(50 \mathrm{~g})$ of white plastic beads to minimize soil warming by absorption of radiation. Thermistors and porous ceramic tensiometer tubes (5-mm diameter) were inserted horizontally during packing. One microcosm per treatment was set up in assays on root colonization and in situ activity, and the replicates consisted of groups of two individual plants; three replicate microcosms per treatment were set up in assays on biological control of Pythium ultimum. Microcosms were incubated in a growth chamber (Fitotron; Sanyo Gallenkamp Plc, Loughborough, UK) until the first true leaves ( $2 \mathrm{~mm}$ in length) appeared. Under the chosen soil temperature regimes, this occurred at 8 days at $25^{\circ} \mathrm{C}$, 12 days at $15^{\circ} \mathrm{C}, 29$ days at $7^{\circ} \mathrm{C}, 7$ days at 25 to $35^{\circ} \mathrm{C}, 9$ days at 15 to $25^{\circ} \mathrm{C}, 11$ days at 3 to $25^{\circ} \mathrm{C}, 13$ days at 10 to $20^{\circ} \mathrm{C}$, and 26 days at 3 to $12^{\circ} \mathrm{C}$ (lower values are night and higher values are day temperatures on a $12 \mathrm{~h} / 12 \mathrm{~h}$ [night/day] cycle). These times were used for root colonization experiments but were 
extended by a factor of 1.17 for antagonist activity experiments to allow more time for disease development. Relative humidity was $85 \%$ and light irradiance (measured at bead layer surface), was 309 to $510 \mu \mathrm{mol} \mathrm{m} \mathrm{m}^{-2} \mathrm{~s}^{-1}$ of photosynthetic active radiation. The air temperature at night was set to the target soil temperature. During daytime it was set $5^{\circ} \mathrm{C}$ lower than the target soil temperature to counteract soil warming caused by absorbed radiation. In experiments involving different matric potentials, volumetric water content was monitored at $3.2,11.5$, and $19.5 \mathrm{~cm}$ soil depth with theta probes type ML1 and a DL3000 datalogger (Delta-T Devices, Cambridge, UK). For the $-10 \times 10^{3} \mathrm{~Pa}$ target regime, matric potential and temperature were monitored at 2 and $10 \mathrm{~cm}$ soil depth with SKT 600S/I pressure sensors attached to the ceramic tensiometers and SKT 200U/I temperature sensors using Skye DataHog 1 and 2 dataloggers, respectively (Skye Instruments, Powys, UK). The probes were placed in microcosms that had not received the antagonist treatment but were otherwise identical to the other microcosms in each treatment. The matric potential of the drier regimes $\left(-100 \times 10^{3}\right.$ and $-300 \times$ $10^{3} \mathrm{~Pa}$ ) was monitored in separate microcosms (nine per treatment) sown with untreated seed pellets by destructive sampling. Three replicate microcosms were sampled destructively at three times $(48 \mathrm{~h}$ after sowing, and $36 \mathrm{~h}$ after the first and second watering). These microcosms were sealed in a plastic bag with a wet paper towel and stored for 24 to $48 \mathrm{~h}$ at $20^{\circ} \mathrm{C}$ to equilibrate at the measurement temperature. Four replicate soil samples from the four corners of each microcosm were then taken at 3.2 and $11.5 \mathrm{~cm}$ depth and immediately measured with the thermocouple psychrometer. Theta probes were used at the same time to measure water content at each depth. To maintain a constant matric potential during the experimental runs, microcosms were watered regularly by injecting water with a syringe through rubber seals (Suba-Seal; Fisher Scientific, Loughborough, UK) at five depths $(2.3,6.2,10.5,14.2$, and $18.2 \mathrm{~cm})$ on two opposite sides of the microcosms. Theta probe readings in control microcosms were used to calculate the distribution of water loss down the microcosms, and appropriate amounts of water were added at each depth to replace loss. Twenty percent more water than the actual weight loss was added to compensate for hysteresis because the aim was to restore the original matric potential. In experiments with different temperature regimes, where no theta probes were employed and water loss was determined by weighing, the same quantity of water was added at each depth.

Seed treatment. Pseudomonas fluorescens B5 was cultured overnight (in $150-\mathrm{ml}$ batches at $24^{\circ} \mathrm{C}, 200 \mathrm{rpm}$ on a rotary shaker) in Luria-Bertani (LB) medium (10 g of yeast extract per liter, $10 \mathrm{~g}$ of tryptone per liter, both from Oxoid Ltd., Hampshire, $\mathrm{UK}$, and $5 \mathrm{~g}$ of $\mathrm{NaCl}$ per liter). B. subtilis MBI 600 was cultured 4 days under the same conditions in baffled flasks $\left(500 \mathrm{ml}, 30^{\circ} \mathrm{C}\right.$, $\mathrm{LB}$ medium $+0.267 \mathrm{~g}$ of $\mathrm{MnSO}_{4} \cdot 4 \mathrm{H}_{2} \mathrm{O}$ ). When lux-marked strains were cultured, the appropriate antibiotics were added to the medium, including $20 \mathrm{ppm}$ of tetracycline (tetracycline hydrochloride; Merck, Darmstadt, Germany) in experiments with Pseudomonas fluorescens B5 and 50 ppm of erythromycin and 25 ppm of chloramphenicol (both Sigma-Aldrich Co., Dorset, UK) in experiments with $B$. subtilis MBI 600. The cultures were centrifuged (Pseudomonas fluorescens at 2,710 $\mathrm{g}$ and $B$. subtilis at $2,556 \mathrm{~g}$ for $20 \mathrm{~min}$ at $4^{\circ} \mathrm{C}$ ). Seeds were pelleted in a rotating vessel (Trybuhl DS 20.FU; Trybuhl Dragiertechnik GmbH, Einbeck, Germany) at $45 \mathrm{rpm}$. Pelleting mass (KWS recipe 13) and adhesive (KWS recipe 4) were obtained from KWS SAAT AG, Einbeck, Germany. To 6,000 seeds, $68 \mathrm{~g}$ of pelleting mass was added and $140 \mathrm{ml}$ of a $2 \%$ adhesive solution was sprayed with a pneumatic pistol (SATA LM-92; SATA Farbspritztechnik GmbH, Kornwestheim, Germany). In treatments involving B. subtilis, cells from a sporulating culture of $B$. subtilis MBI 600 (4 days old) were suspended in the $140-\mathrm{ml}$ adhesive solution used for pelleting. The treatment resulted in a bacterial inoculum of $10^{6}$ to $10^{7} \mathrm{CFU}$ per seed pellet, consisting mainly (60 to $100 \%$ ) of spores; this was determined by suspending 10 seeds in 1/4-strength Ringers solution (Oxoid Ltd.) and plating serial dilutions. Pseudomonas fluorescens was applied by soaking pelleted seeds (with and without $B$. subtilis incorporated) for $15 \mathrm{~min}$ in a suspension of the antagonist $\left(\mathrm{OD}_{550 \mathrm{~nm}}=5\right.$, suspended in 1/4-strength Ringers solution). This treatment resulted in a Pseudomonas inoculum of $10^{7}$ to $10^{8} \mathrm{CFU}$ per seed pellet. After soaking, the seeds were air-dried for $1 \mathrm{~h}$ under a laminar flow hood and then sown immediately.

Pythium inoculation and disease assessment. Pea seeds (marrowfat peas, Great Scot, Scotia Haven Foods Ltd., Warrington, UK) were pregerminated in water for $24 \mathrm{~h}$ and homogenized for 30 to $60 \mathrm{~s}$ in a blender. Thirty-five grams of homogenized peas was spread in a 9-cm-diameter glass petri dish. The petri dishes were autoclaved three times for $20 \mathrm{~min}$ at $121^{\circ} \mathrm{C}$. They were then inoculated using three agar plugs of 3-day-old corn meal agar cultures of Pythium ultimum and incubated at $25^{\circ} \mathrm{C}$ for 4 days. Inoculated pea mash (14.3 g per microcosm) was crumbled and mixed gently into the soil after adjustment of its water content. Infested soil was incubated in plastic bags for 3 days at room temperature before the start of the experiment. Only the upper $9 \mathrm{~cm}$ of the microcosm consisted of infested soil. Noninfested controls were not included in antagonist assays because "noninfested" soil contained some natural inoculum $(\approx 70$ to $90 \%$ seeds emerged in assays on root colonization and up to $30 \%$ of recovered plants had symptoms). At the end of the experiment, shoots (i.e., all plant parts above seed level) of all apparently healthy (symptomless) plants in three replicate microcosms per treatment were recovered, counted, and collected for dry weight determination. Shoots of plants that showed typical symptoms of Pythium damping-off such as brown discoloration or dry thin sections of the hypocotyl (in a later stage of disease development) were discarded.

Plant colonization assays. Three replicates, each consisting of two plants, were sampled within one microcosm. In preliminary experiments, untreated seeds and seeds treated with Pseudomonas fluorescens B5 or spores of $B$. subtilis MBI 600 were sown in the same microcosm in close vicinity $(2$ to $3 \mathrm{~cm}$ ); no cells of the antagonists could be detected on the roots and hypocotyls of the plants originating from the untreated seeds (unpublished data). Thus, it could be concluded that there was no substantial root-toroot travel of the antagonists, and sets of plants taken within one microcosm could be considered truly independent replicates. Plants were dissected into the hypocotyl ( 0 to $2 \mathrm{~cm}$ above seed level), 0 to $2 \mathrm{~cm}$ root depth, 2 to $4 \mathrm{~cm}$ root depth, and 4 to $6 \mathrm{~cm}$ root depth; the respective sections from the two plants of one replicate were then processed as one sample. Two milliliters of 1/4-strength Ringers solution was added to the root and hypocotyl samples, and samples were vortexed and sonicated (Decon Ultrasonic Bath; Decon Laoratories, East Sussex, UK) for $3 \mathrm{~min}$ (Pseudomonas fluorescens) or $5 \mathrm{~min}$ (B. subtilis). The resultant suspension was used for dilution plating (CFU counts) and luminescence measurements (described below). In combined treatments, the dilution series for Pseudomonas spp. were plated after 3 min sonication; the sample was sonicated 2 min further; and the dilution series for detection of $B$. subtilis were performed. No luminometry was performed in the mixed treatments. From each dilution step, three 10- $\mu$ d drops were placed on LB plates with appropriate antibiotics (described previously). For spore counts, samples containing $B$. subtilis MBI 600 were subjected to heat treatment $\left(80^{\circ} \mathrm{C}, 10 \mathrm{~min}\right)$ and plated again. No tetracycline-resistant indigenous flora was found in samples of untreated control plants, whereas chloramphenicol- and erythromycin-resistant soil bacteria grew on isolation plates in some experiments. However, B. subtilis MBI 600 could be distinguished by the distinct morphology of its colonies. 
Measurement of luminescence. Bioluminescence was measured as relative luminescence units (RLU) according to Rattray et al. (47). For Pseudomonas sp., luminescence was recorded 3 min after the addition of $10 \mu \mathrm{l}$ of $5 \%$ n-decyl aldehyde (dissolved in $96 \%$ ethanol) to $1 \mathrm{ml}$ of the sonicated sample by a luminometer (Biorbit LKB 1251; Labtech International, Uckfield, UK). The measuring times were $3 \times 2 \mathrm{~s}$ after $4 \mathrm{~s}$ shaking. For B. subtilis, bioluminescence was immediately measured after addition of $10 \mu \mathrm{l}$ of $0.05 \% n$-decyl aldehyde to $1 \mathrm{ml}$ of sonicated sample by a Jade portable luminometer (Labtech Inc., Andover, MA). Values measured in samples from control plants that grew in the same soil type but did not receive antagonist treatment were subtracted as blank values. No luminometry was performed in the combined inoculum treatments.

Statistical analysis. For data analysis of antagonist assays, the number of healthy plants were calculated as percentages (16 seeds per microcosms $=100 \%$ ), and where necessary, data were arcsine square root-transformed; plant fresh weight data were square root-transformed to obtain normally distributed residuals. Temperature regimes were treated like qualitative factors and Tukey's honesty significant difference test was applied to determine the effect of antagonist treatment within each temperature regime and the effect of temperature regime within each antagonist treatment. To investigate the quantitative factors soil temperature and matric potential on antagonistic activity (number and dry weight of healthy plants in presence and absence of treatment), a multiple linear regression model was used.
For the experiment on the effect of temperature regimes, day temperature and night temperature were entered as two separate factors. The antagonists were introduced into this model as two separate numerical factors with the values 0 (absent) and 1 (present). Factors were entered stepwise according to their contribution to the relationship (i.e., their correlation with the dependent variable) starting with the variables showing highest correlation. In a backward procedure, all four variables ([i], day temperature, night temperature, Pseudomonas fluorescens, and B. subtilis; or [ii], soil temperature, matric potential, Pseudomonas fluorescens, and B. subtilis) were entered and insignificant ones were removed. The validity of the model was checked by testing residuals for normal distribution and trend with increasing $x$ value. In root colonization assays, population sizes and densities (CFU) and RLU measurements were log-transformed before analysis of variance (ANOVA). A mixed (split plot) ANOVA (27) was performed with root depth as a repeated measure within one subject and all other factors (soil matric potential, soil temperature, and combination with the respective other antagonist strain) as independent (between subject) factors; the least significant difference (LSD) was calculated. If Mauchley's test of sphericity was significant, degrees of freedom were adjusted according to Greenhouse-Geiser as described by Howell (22). The effect of matric potential was investigated at each depth using linear and quadratic regression. Statistical analyses were performed with SPSS release 9.0.0 (SPSS Inc., Chicago).

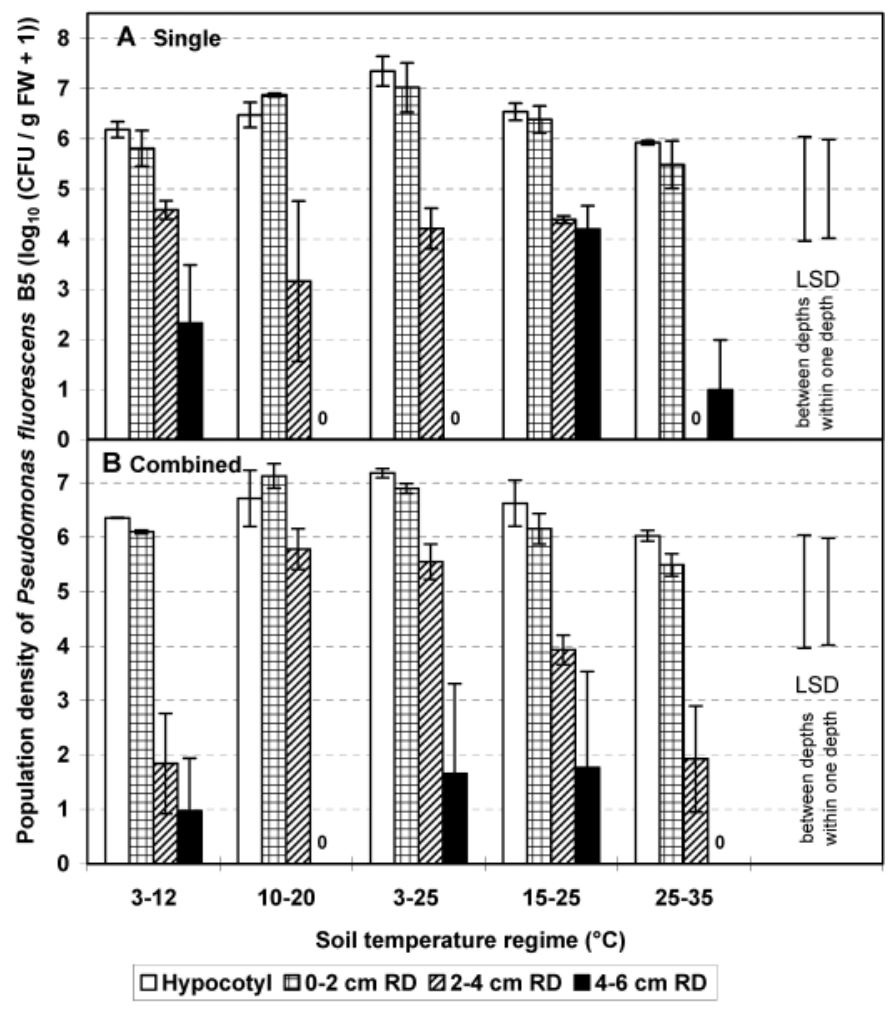

Fig. 1. Influence of different soil temperature regimes on the population density of Pseudomonas fluorescens B5 (lux-marked strain L9) on sugar beet seedlings on the hypocotyl and at different root depths (RD). Mean \pm standard error. FW $=$ plant fresh weight. A, Single antagonist treatment with Pseudomonas fluorescens B5. B, Combined inoculum with Pseudomonas fluorescens and Bacillus subtilis MBI 600; only Pseudomonas fluorescens was counted. Matric potential was between $-6 \times 10^{3}$ and $-18 \times 10^{3} \mathrm{~Pa}$. Three replicates, each consisting of two plants, were recovered without seed pellet when they started to develop true leaves. Least significant difference (LSD) was calculated at $P=0.05$. Significant factor effects are shown in Table 3.

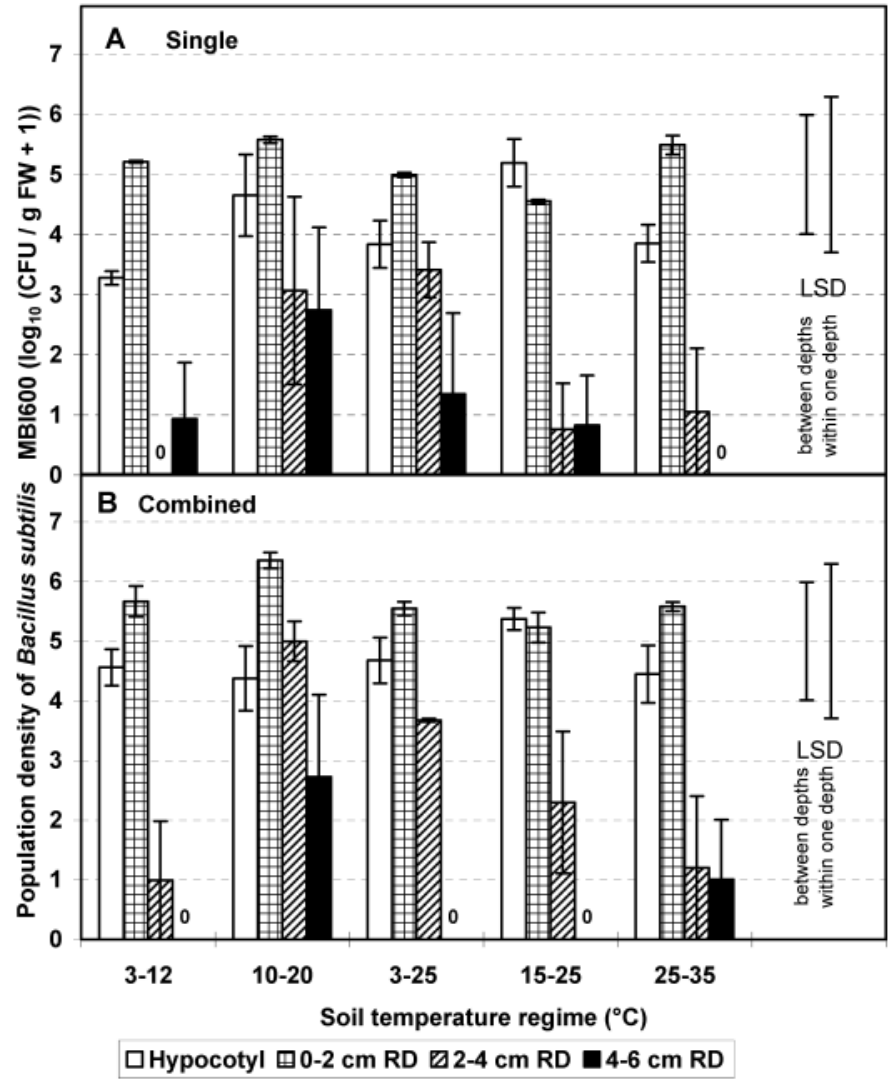

Fig. 2. Influence of different soil temperature regimes on the population density of Bacillus subtilis MBI 600 (lux-marked strain 33) on sugar beet seedlings on the hypocotyl and at different root depths (RD). Mean \pm standard error. $\mathrm{FW}=$ plant fresh weight. Matric potential was between $-6 \times 10^{3}$ and $-18 \times 10^{3} \mathrm{~Pa}$. A, Single antagonist treatment with $B$. subtilis. B, Combined inoculum with Pseudomonas fluorescens B5 and B. subtilis; only B. subtilis was counted. B. subtilis was applied and recovered as spores. Three replicates, each consisting of two plants, were recovered without seed pellet when they started to develop true leaves. Least significant difference (LSD) was calculated at $P=0.05$. Significant factor effects are shown in Table 3 . 


\section{RESULTS}

General observations. Pseudomonas fluorescens B5 reached higher average population densities than B. subtilis MBI 600 (6 to 7 compared with 5 to $6 \log \mathrm{CFU} / \mathrm{g}$ fresh weight) in the upper regions (Figs. 1 to 5). In all treatments, both antagonists reached highest population densities in the hypocotyl region and the upper root ( 0 to $2 \mathrm{~cm}$ depth) and population density decreased significantly with root depth (Figs. 1 to 5). This decrease was more pronounced in $B$. subtilis, whose population densities were mostly near the detection limit $\left(10^{1}-10^{2} \mathrm{CFU} / \mathrm{g}\right.$ root fresh weight) below $4 \mathrm{~cm}$ root depth (Figs. 2, 3, and 5). The population densities of $B$. subtilis MBI 600 determined after heat treatment were mostly as high or even higher (by 1.2- to 6-fold) than the population density determined before heat treatment (Tables 1 and 2). This indicated that the population of B. subtilis MBI 600 consisted largely of (dormant) spores, which were activated by heat treatment, whereas there were no or only a minor proportion of vegetative cells. Thus, only population densities based on spore counts are shown (Figs. 2, 3, and 5).

Matric potentials decreased steadily after each watering, and it was only possible to maintain them within a range (approximately $-6 \times 10^{3}$ to $-18 \times 10^{3} \mathrm{~Pa}$ for the $-10 \times 10^{3} \mathrm{~Pa}$

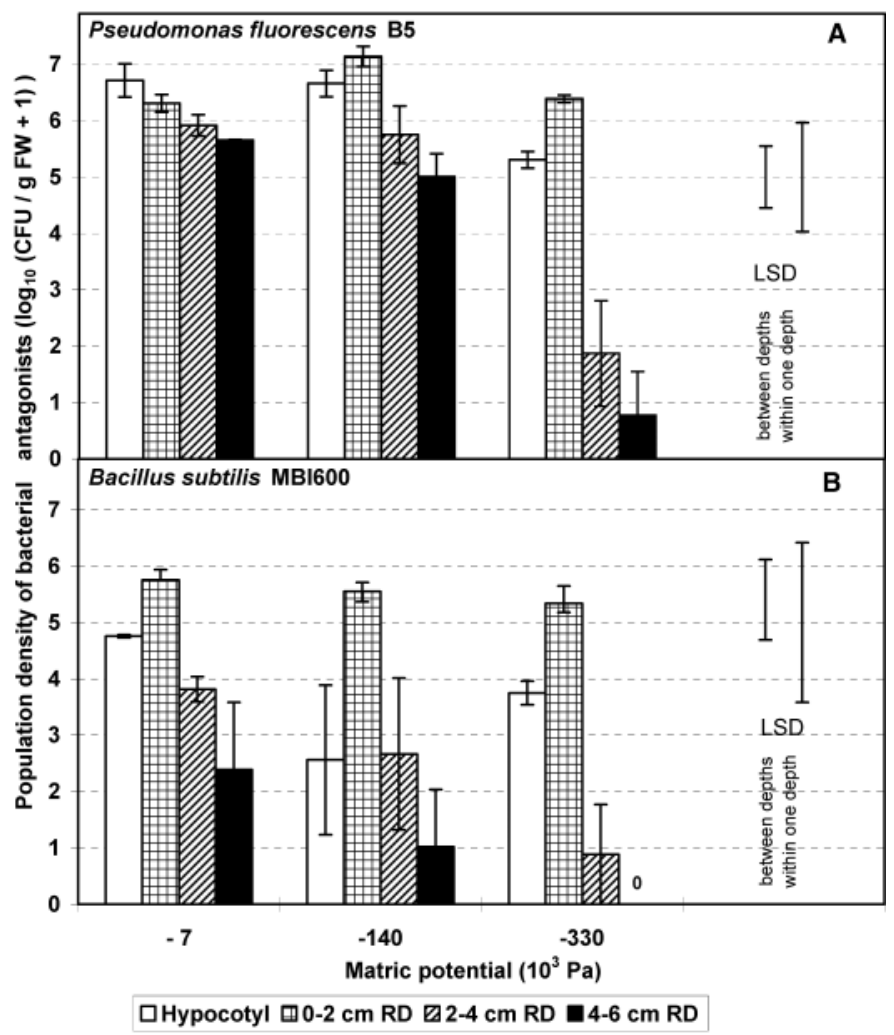

Fig. 3. Population density of A, Pseudomonas fluorescens B5 (lux-marked strain L9) and B, Bacillus subtilis MBI 600 (lux-marked strain 33) at different matric potentials on sugar beet seedlings on the hypocotyl and at different root depths $(\mathrm{RD})$. Mean \pm standard error. $\mathrm{FW}=$ plant fresh weight. Soil temperature was $15^{\circ} \mathrm{C}$ (range 14 to $19^{\circ} \mathrm{C}$ ). B. subtilis was applied and recovered as spores. Three replicates, each consisting of two plants, were recovered without seed pellet when they started to develop true leaves. The main effect of root depth $(P<0.001)$ was significant for both strains, whereas matric potential had a significant effect only on Pseudomonas fluorescens $(P<0.001$, significant interaction with depth at $P<0.001)$. Based on linear regression, there was a significant decrease in colony forming units of Pseudomonas fluorescens with decreasing matric potential at three depths (hypocotyl: $R^{2}=0.6807, P=0.006 ; 2$ to $4 \mathrm{~cm}$ root depth: $R^{2}=0.7016, P=$ 0.005 ; and 4 to $6 \mathrm{~cm}$ root depth: $R^{2}=0.8234, P=0.0007$ ). A decrease in colony forming units of $B$. subtilis with decreasing matric potential was significant at 2 to $4 \mathrm{~cm}$ depth $\left(R^{2}=0.4481, P=0.049\right)$. Least significant difference (LSD) was calculated at $P=0.05$. target value and $-70 \times 10^{3}$ to $-180 \times 10^{3}$ for the $-100 \times 10^{3} \mathrm{~Pa}$ target value).

Influence of soil temperature regime on rhizosphere and hypocotyl colonization by Pseudomonas fluorescens B5 and $B$. subtilis MBI 600. Four different soil temperature regimes with a diurnal fluctuation amplitude of approximately $10^{\circ} \mathrm{C}\left(3\right.$ to $10^{\circ} \mathrm{C}$, 10 to $20^{\circ} \mathrm{C}, 15$ to $25^{\circ} \mathrm{C}$, and 25 to $35^{\circ} \mathrm{C}$ ) and a regime with an amplitude of $22^{\circ} \mathrm{C}$ ( 3 to $25^{\circ} \mathrm{C}$ ) were compared in soil at a target matric potential of $-10 \times 10^{3} \mathrm{~Pa}$. Soil temperature regime had a significant influence on Pseudomonas fluorescens population per seedling and on population density for different parts of the plant $(P<0.001)$ (Fig. 1; Tables 1 and 3). There was a significant interaction between temperature regime and root depth, indicating that temperature regime affected the distribution of the population along the root $(P<0.001$; Table 3$)$. The total population size was significantly reduced at high temperatures $\left(25\right.$ to $\left.35^{\circ} \mathrm{C}\right)$ compared with all other soil temperature regimes (Table 1). In addition, the population showed a sharper decline with depth at 25 to $35^{\circ} \mathrm{C}$. Below $4 \mathrm{~cm}$ depth, population densities of Pseudomonas fluorescens B5 were at or beyond the detection limit in both the single and combined antagonist treatments (Fig. 1). No consistent significant differences were apparent between the other four temperature regimes $\left(3\right.$ to $12^{\circ} \mathrm{C}, 10$ to $20^{\circ} \mathrm{C}, 3$ to $25^{\circ} \mathrm{C}$, and 15 to $25^{\circ} \mathrm{C}$ ) in the single or combined treatment. Based on a comparison between the 3 to $25^{\circ} \mathrm{C}$ regime with the temperature regimes with similar day or night temperatures but smaller amplitudes ( 3 to $12^{\circ} \mathrm{C}, 15$ to $25^{\circ} \mathrm{C}$ ), the increase in diurnal temperature fluctuation had no significant effect (Fig. 1). The addition of $B$. subtilis

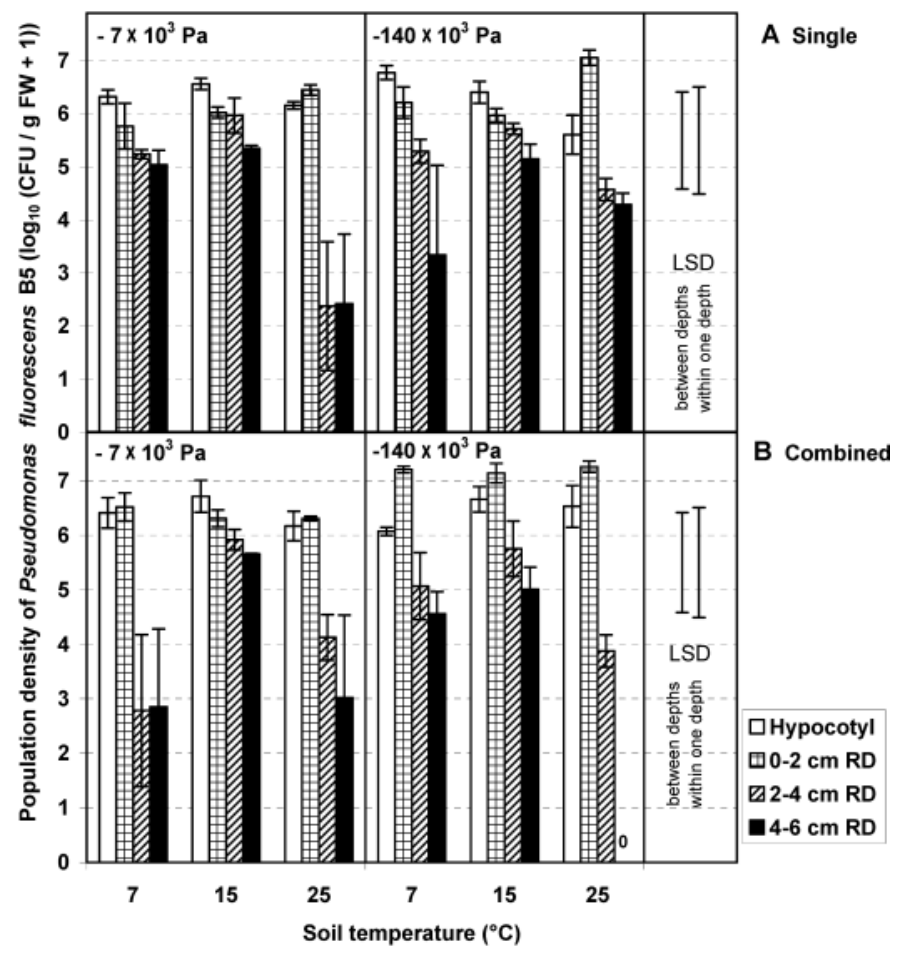

Fig. 4. Combined influences of soil matric potential and soil temperature on the population density of Pseudomonas fluorescens B5 (lux-marked strain L9) on sugar beet seedlings on the hypocotyl and at different root depths (RD). Mean \pm standard error. A, Single antagonist treatment with Pseudomonas fluorescens. B, Combined inoculum of Pseudomonas fluorescens and Bacillus subtilis MBI 600; only Pseudomonas fluorescens was counted. FW = plant fresh weight. Temperatures and matric potentials represent means: a diurnal fluctuation of 3 to $5^{\circ} \mathrm{C}$ was observed and soil matric potentials ranged from $-5 \times 10^{3}$ and $-10 \times 10^{3} \mathrm{~Pa}$ and from $-120 \times 10^{3}$ and $-180 \times 10^{3} \mathrm{~Pa}$, respectively. Three replicates, each consisting of two plants, were recovered without seed pellet when they started to develop true leaves. Least significant difference (LSD) was calculated at $P=0.05$. Significant factor effects are shown in Table 4. 
MBI 600 also had no significant effect on the population density of Pseudomonas fluorescens B5 (Fig. 1; Table 3).

Total population size of B. subtilis MBI 600 was not affected by temperature regime (Tables 1 and 3), but temperature regime did affect the population density of $B$. subtilis MBI 600 in different sections $(P=0.007)$ and its distribution along the root $(P=$ 0.001) (Fig. 2; Table 3). Population density and colonization down the root were increased in the 10 to $20^{\circ} \mathrm{C}$ regime compared

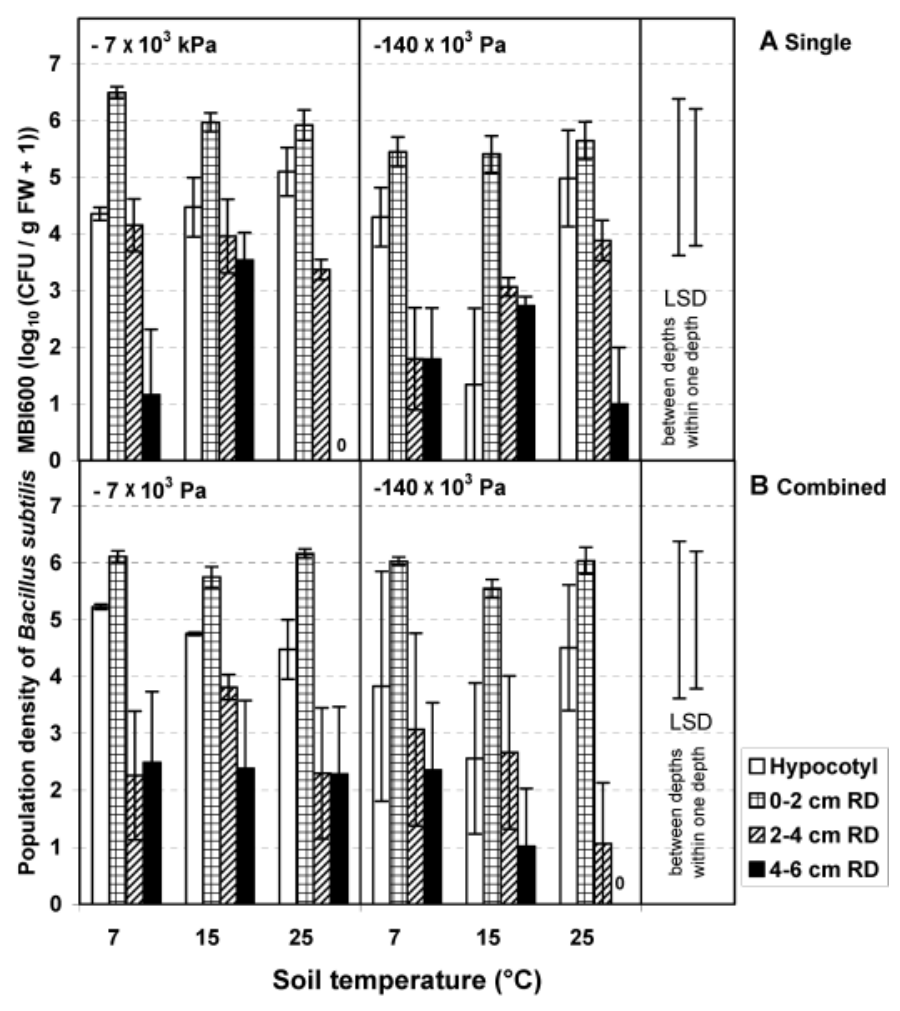

Fig. 5. Combined influences of soil matric potential and soil temperature on the population density of Bacillus subtilis MBI 600 on sugar beet seedlings on the hypocotyl and at different root depths (RD). Mean \pm standard error. A, Single antagonist treatment with $B$. subtilis. B, Combined inoculum with Pseudomonas fluorescens B5 and B. subtilis; only B. subtilis was counted. $\mathrm{FW}=$ plant fresh weight. Temperatures and matric potentials represent means: a diurnal fluctuation of 3 to $5^{\circ} \mathrm{C}$ was observed and soil matric potentials ranged from $-5 \times 10^{3}$ and $-10 \times 10^{3} \mathrm{~Pa}$ and from $-120 \times 10^{3}$ and $-180 \times 10^{3} \mathrm{~Pa}$, respectively. Three replicates, each consisting of two seedlings, were recovered without seed pellet when they started to develop true leaves. B. subtilis was applied and recovered as spores. Least significant difference (LSD) was calculated at $P=0.05$. Significant factor effects are shown in Table 4. with regimes with very low $\left(3\right.$ to $\left.12^{\circ} \mathrm{C}\right)$ and higher $\left(15\right.$ to $25^{\circ} \mathrm{C}$, 25 to $35^{\circ} \mathrm{C}$ ) temperatures. Downward colonization also was increased in the temperature regime with the largest diurnal amplitude $\left(3\right.$ to $25^{\circ} \mathrm{C}$ ) (Fig. 2). However, this observation could not be reproduced when the experiment was repeated (data not shown). The addition of Pseudomonas fluorescens B5 in a combined inoculum had no significant effect on the rhizosphere populations of B. subtilis MBI 600 (Table 3).

Influence of soil matric potential on rhizosphere and hypocotyl colonization by Pseudomonas fluorescens B5 and $B$. subtilis MBI 600. In the range of $-7 \times 10^{3}$ to $-330 \times 10^{3} \mathrm{~Pa}$, matric potential significantly affected the population density and distribution of Pseudomonas fluorescens B5 along the root at $15^{\circ} \mathrm{C}$ $(P<0.001)$ (Fig. 3). Based on linear and quadratic regression, there was a significant decrease in population density of Pseudomonas fluorescens B5 with decreasing matric potential at 2 to $4 \mathrm{~cm}$ root depth $\left(R^{2}=0.702\right.$ or 0.81 , respectively; $\left.P<0.006\right)$ and at 4 to $6 \mathrm{~cm}$ depth $\left(R^{2}=0.8234\right.$ or 0.902 , respectively; $\left.P<0.001\right)$. The significant decrease occurred between $-140 \times 10^{3}$ and $-330 \times$ $10^{3} \mathrm{~Pa}$ (Fig. 3). Colonization of deeper parts of the root system (below $2 \mathrm{~cm}$ depth) by Pseudomonas fluorescens B5 was significantly reduced under very dry conditions $\left(-330 \times 10^{3} \mathrm{~Pa}\right)$ (Fig. 3). A similar trend also was observed for B. subtilis MBI 600 (Fig. $3)$, but the decrease in the rhizosphere population with decreasing matric potential was significant only at 2 to $4 \mathrm{~cm}$ root depth $\left(R^{2}=\right.$ $0.4481 ; P=0.049$ ).

Combined influence of soil temperature and matric potential on sugar beet rhizosphere colonization by Pseudomonas fluorescens $\mathrm{B5}$ and $\boldsymbol{B}$. subtilis MBI 600. At the lowest matric potential $\left(-330 \times 10^{3} \mathrm{~Pa}\right)$, emergence was very low (zero to two plants), even without Pythium ultimum, and it was not influenced by amendments either with Pythium ultimum or with antagonists (data not shown). This indicated that soil dryness, rather than Pythium ultimum, was the limiting factor for emergence. At the intermediate range $\left(-70 \times 10^{3}\right.$ to $\left.-180 \times 10^{3} \mathrm{~Pa}\right)$, no adverse effects of soil dryness on emergence were observed. Consequently, the matric potentials $-7 \times 10^{3} \mathrm{~Pa}$ and intermediate matric potentials $\left(-100 \times 10^{3} \mathrm{~Pa}\right.$ target value; real average value $-120 \times 10^{3}$ to $-140 \times 10^{3} \mathrm{~Pa}$ ) were chosen to investigate the combined effects of matric potential and temperature on the antagonistic bacteria. The average soil temperatures were 7,15 , and $25^{\circ} \mathrm{C}$; diurnal soil temperature fluctuations of about $5^{\circ} \mathrm{C}$ were unavoidable even when the air temperature was lowered during the day to counteract soil warming.

Matric potential and amendment of B. subtilis MBI 600 had a significant effect on the total recovered population per plant of Pseudomonas fluorescens B5 $(P<0.001)$ (Tables 2 and 4$)$. The factor "combination with $B$. subtilis" interacted significantly with both temperature $(P=0.003)$ and matric potential $(P=$ 0.005). The total recovered population of Pseudomonas fluores-

TABLE 1. Influence of different soil temperature regimes on the total recovered population of each antagonist per sugar beet seedling (log CFU per plant) at a target matric potential of $-10 \times 10^{3} \mathrm{~Pa}$ (range $-6 \times 10^{3}$ to $\left.-18 \times 10^{3} \mathrm{~Pa}\right)^{\mathrm{a}}$

\begin{tabular}{|c|c|c|c|c|c|c|}
\hline \multirow{2}{*}{$\begin{array}{l}\text { Soil temperature } \\
\text { regime }\left({ }^{\circ} \mathrm{C}\right)\end{array}$} & \multicolumn{2}{|c|}{ Pseudomonas fluorescens B5 } & \multicolumn{2}{|c|}{ Bacillus subtilis MBI 600 (spores) $^{\mathrm{b}}$} & \multicolumn{2}{|c|}{$\begin{array}{c}\text { B. subtilis MBI } 600 \\
\text { (vegetative cells }+ \text { spores) }^{\mathrm{c}}\end{array}$} \\
\hline & Single & Combined & Single & Combined & Single & Combined \\
\hline $3-12$ & $5.4 \pm 0.19$ & $5.5 \pm 0.04$ & $4.4 \pm 0.19$ & $4.5 \pm 0.25$ & $4.7 \pm 0.39$ & $5.4 \pm 0.15$ \\
\hline $10-20$ & $5.7 \pm 0.05$ & $6.0 \pm 0.07$ & $4.2 \pm 0.13$ & $4.7 \pm 0.33$ & $4.1 \pm 0.07$ & $4.7 \pm 0.35$ \\
\hline $3-25$ & $6.0 \pm 0.05$ & $5.7 \pm 0.08$ & $4.0 \pm 0.07$ & $4.2 \pm 0.17$ & $4.4 \pm 0.38$ & $4.2 \pm 0.19$ \\
\hline $15-25$ & $5.7 \pm 0.11$ & $5.5 \pm 0.14$ & $3.9 \pm 0.17$ & $4.3 \pm 0.14$ & $4.3 \pm 0.12$ & $4.3 \pm 0.10$ \\
\hline $25-35$ & $4.8 \pm 0.24$ & $4.7 \pm 0.16$ & $4.4 \pm 0.25$ & $4.4 \pm 0.08$ & $5.1 \pm 0.21$ & $4.7 \pm 0.07$ \\
\hline LSD & \multicolumn{2}{|c|}{0.39} & \multicolumn{2}{|c|}{0.57} & \multicolumn{2}{|c|}{0.69} \\
\hline
\end{tabular}

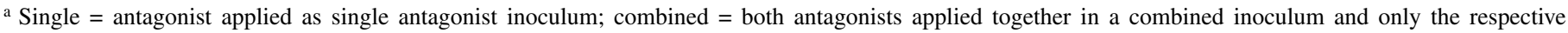
antagonist counted. Each value (mean \pm standard error) represents three replicates (two plants per replicate), recovered without seed pellet when they started to develop true leaves. Least significant difference (LSD) calculated at $P=0.05$. Significant factor effects are shown in Table 3 .

b Samples subjected to heating $\left(80^{\circ} \mathrm{C}, 10 \mathrm{~min}\right)$ before plating.

c Samples not heated before plating. 
cens B5 was significantly increased at the lower matric potential of $-140 \times 10^{3} \mathrm{~Pa}$, especially in a mixed inoculum with $B$. subtilis MBI 600 (Table 2). Colonization of the upper root regions (0 to $2 \mathrm{~cm}$ depth) was slightly increased in these treatments (Fig. 4). However, these observations in the hypocotyl section and the upper root (0 to $2 \mathrm{~cm} \mathrm{depth)}$ were only trends. The main differences between the matric potential $\times$ temperature combinations were below $2 \mathrm{~cm}$ depth (Fig. 4). Although it affected the total population of Pseudomonas fluorescens B5 per plant, there was no significant effect of matric potential on population density per gram of plant fresh weight (Table 4). However, temperature, which had no effect on total population size, affected the distribution of Pseudomonas fluorescens B5 along the root $(P<0.001)$ (Table 4; Fig. 4). Colonization of lower root regions was greatest at intermediate temperatures (15 to $20^{\circ} \mathrm{C}$ ). Colonization decreased under cooler and warmer conditions at both matric potentials in both single and combined inocula treatments (Fig. 4). The factor "amendment with $B$.

TABLE 2. Total recovered populations per seedling (log CFU per plant) of the antagonists Pseudomonas fluorescens B5 and Bacillus subtilis MBI 600 at different temperatures and matric potentials ${ }^{\mathrm{a}}$

\begin{tabular}{|c|c|c|c|c|c|c|c|}
\hline \multirow{2}{*}{$\begin{array}{l}\text { Matric potential } \\
\left(\times 10^{3} \mathrm{~Pa}\right)\end{array}$} & \multirow{2}{*}{$\begin{array}{l}\text { Soil temperature } \\
\left({ }^{\circ} \mathrm{C}\right)\end{array}$} & \multicolumn{2}{|c|}{ Pseudomonas fluorescens B5 } & \multicolumn{2}{|c|}{ B. subtilis MBI 600 (spores) $^{\mathrm{b}}$} & \multicolumn{2}{|c|}{ B. subtilis MBI 600 (vegetative cells + spores) ${ }^{c}$} \\
\hline & & Single & Combined & Single & Combined & Single & Combined \\
\hline-7 & 7 & $5.3 \pm 0.23$ & $5.8 \pm 0.20$ & $5.1 \pm 0.55$ & $4.9 \pm 0.49$ & $5.1 \pm 0.56$ & $5.4 \pm 0.21$ \\
\hline-7 & 15 & $5.6 \pm 0.06$ & $5.9 \pm 0.04$ & $5.3 \pm 0.03$ & $5.1 \pm 0.12$ & $5.3 \pm 0.07$ & $5.3 \pm 0.09$ \\
\hline-140 & 7 & $5.6 \pm 0.21$ & $6.5 \pm 0.04$ & $4.7 \pm 0.21$ & $5.4 \pm 0.06$ & $4.8 \pm 0.28$ & $5.3 \pm 0.10$ \\
\hline-140 & 15 & $5.7 \pm 0.11$ & $6.5 \pm 0.04$ & $4.9 \pm 0.31$ & $4.9 \pm 0.10$ & $4.9 \pm 0.35$ & $4.7 \pm 0.35$ \\
\hline-140 & 25 & $6.4 \pm 0.16$ & $6.6 \pm 0.06$ & $4.9 \pm 0.11$ & $5.5 \pm 0.11$ & $5.0 \pm 0.13$ & $5.4 \pm 0.10$ \\
\hline
\end{tabular}

${ }^{a}$ Single $=$ antagonist applied as single inoculum; combined $=$ a combined inoculum of Pseudomonas fluorescens and B. subtilis was applied. Each value (mean \pm standard error) represents three replicates (two plants per replicate), recovered without seed pellet when they started to develop true leaves. Least significant difference (LSD) calculated at $P<0.05$ significance level. The main effects of matric potential $(P<0.001)$ and combination with $B$. subtilis MBI $600(P<$ 0.001) on Pseudomonas fluorescens B5 populations were significant. Significant factor effects are shown on Table 4.

${ }^{\mathrm{b}}$ Samples subjected to heating $\left(80^{\circ} \mathrm{C}, 10 \mathrm{~min}\right)$ before plating.

${ }^{\mathrm{c}}$ Samples not heated before plating.

TABLE 3. Influence of the main factors soil temperature, combination with the other strain (application in a combined inoculum) and root depth and the interactions of these factors on root colonization by the antagonists Pseudomonas fluorescens B5 and Bacillus subtilis MBI 600"

\begin{tabular}{|c|c|c|c|c|}
\hline \multirow[b]{3}{*}{ Factors and factor interactions } & \multicolumn{4}{|c|}{ Temperature regime experiment } \\
\hline & \multicolumn{2}{|c|}{ Pseudomonas fluorescens B5 } & \multicolumn{2}{|c|}{ B. subtilis MBI 600} \\
\hline & $\begin{array}{l}\text { Total population } \\
\text { per plant }\end{array}$ & $\begin{array}{l}\text { Population density } \\
\text { along the root }\end{array}$ & $\begin{array}{l}\text { Total population } \\
\text { per plant }\end{array}$ & $\begin{array}{l}\text { Population density } \\
\text { along the root }\end{array}$ \\
\hline Temperature & $<0.001$ & $<0.001$ & NS & 0.007 \\
\hline Root depth & $\ldots$ & $<0.001$ & $\ldots$ & $<0.001$ \\
\hline Combination with other strain & NS & NS & NS & NS \\
\hline Root depth $\times$ temperature & $\ldots$ & 0.001 & $\ldots$ & 0.001 \\
\hline Temperature $\times$ combination with other strain & NS & NS & NS & NS \\
\hline Root depth $\times$ combination with other strain & $\ldots$ & NS & $\ldots$ & NS \\
\hline Root depth $\times$ temperature $\times$ combination with other strain & $\ldots$ & NS & $\ldots$ & NS \\
\hline
\end{tabular}

${ }^{a}$ NS $=$ not significant. $P$ values were obtained by three-way analysis of variance (ANOVA) with root depth as within subjects-factor and all other factors as between-subjects factors (described in the text). For total populations per plant, two-way ANOVA was performed. Corresponding data are shown in Table 1 (total populations per plant) and Figures 1 and 2 (population density along the root).

TABLE 4. Influence of the main factors soil temperature, soil matric potential, combination with the other strain (application in a combined inoculum), root depth, and the interactions of these factors on root colonization by the antagonists Pseudomonas fluorescens B5 and Bacillus subtilis MBI 600 ${ }^{\mathrm{a}}$

\begin{tabular}{|c|c|c|c|c|}
\hline \multirow[b]{2}{*}{ Factors and factor interactions } & \multicolumn{2}{|c|}{ Pseudomonas fluorescens B5 } & \multicolumn{2}{|c|}{ B. subtilis MBI 600} \\
\hline & $\begin{array}{l}\text { Total population } \\
\text { per plant }\end{array}$ & $\begin{array}{l}\text { Population density } \\
\text { along the root }\end{array}$ & $\begin{array}{l}\text { Total population } \\
\text { per plant }\end{array}$ & $\begin{array}{l}\text { Population density } \\
\text { along the root }\end{array}$ \\
\hline Temperature & NS & $<0.001$ & NS & NS \\
\hline Combination with other strain & $<0.001$ & NS & NS & NS \\
\hline Root depth & $\ldots$ & $<0.001$ & $\ldots$ & $<0.001$ \\
\hline Temperature $\times$ matric potential & 0.017 & NS & NS & NS \\
\hline Root depth $\times$ temperature & $\ldots$ & $<0.001$ & $\ldots$ & 0.032 \\
\hline Root depth $\times$ matric potential & $\ldots$ & NS & $\ldots$ & NS \\
\hline Root depth $\times$ combination with other strain & 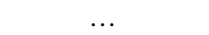 & 0.041 & $\ldots$ & NS \\
\hline Temperature $\times$ matric potential $\times$ combination with other strain & NS & 0.029 & NS & NS \\
\hline Root depth $\times$ temperature $\times$ matric potential & $\ldots$ & NS & $\ldots$ & NS \\
\hline Root depth $\times$ temperature $\times$ combination with other strain & $\ldots$ & NS & $\ldots$ & NS \\
\hline Root depth $\times$ matric potential $\times$ combination with other strain & $\ldots$ & NS & $\ldots$ & NS \\
\hline
\end{tabular}

${ }^{a}$ NS $=$ not significant. $P$ values were obtained by four-way analysis of variance (ANOVA) with root depth as within subjects-factor and all other factors as between-subjects factors (described in text). For total populations per plant, three-way ANOVA was performed. Corresponding data are shown in Table 2 (total populations per plant) and Figures 4 and 5 (population density along the root). 
subtilis" interacted significantly with root depth $(P=0.041)$, matric potential, and temperature $(P=0.029)$, and there was an interaction of all factors together at $P=0.002$ (Table 4). However, no significant general effect of $B$. subtilis MBI 600 on population density of Pseudomonas fluorescens B5 along the root was observable.

In situ bioluminescence of Pseudomonas fluorescens B5 was clearly detectable in all root regions under all combinations of temperature and matric potential (Fig. 6). The highest levels of bioluminescence were measured at the hypocotyl region (Fig. 6), whereas bioluminescence in rhizosphere samples was lower. Temperature rather than matric potential had a significant effect on bioluminescence $(P=0.002)$. Bioluminescence decreased at the highest temperature $\left(25^{\circ} \mathrm{C}\right)$ (Fig. 6). Bioluminescence showed a weak but significant correlation with colony forming units $\left(R^{2}=\right.$ $0.3667 ; P<0.001$ ) (Figs. 4A and 6).

Soil matric potential and temperature had no significant effects on the total recovered population of $B$. subtilis MBI 600 per plant (Tables 2 and 4). The bulk of the B. subtilis population was located on the root 0 to $2 \mathrm{~cm}$ below the seed (Fig. 5). Cell densities of B. subtilis MBI 600 were mostly near the detection limit at $4 \mathrm{~cm}$ below seed level. Matric potential had a significant effect on $B$. subtilis cell and spore densities per gram of root fresh weight $(P=0.009)$ (Table 4). Mostly, cell densities were slightly lower at the lower matric potential of $-140 \times 10^{3} \mathrm{~Pa}$. For both Pseudomonas fluorescens B5 and B. subtilis MBI 600, there were no significant interactions between soil temperature $(7,15$, and $\left.25^{\circ} \mathrm{C}\right)$ and matric potential $\left(-7 \times 10^{3}\right.$ and $\left.-140 \times 10^{3} \mathrm{~Pa}\right)$, except for the total recovered population of Pseudomonas fluorescens B5 (Table 4; Figs. 4 and 5).

Influence of soil temperature regime on antagonistic activity against Pythium ultimum. In soil inoculated with Pythium ultimum, both temperature regime and treatment with Pseudomonas fluorescens B5 significantly affected the number and dry weight of healthy plants $(P<0.001)$ (Fig. 7; Table 5). B. subtilis MBI 600 had no effect and did not significantly improve the antagonistic activity of Pseudomonas fluorescens B5. Addition of

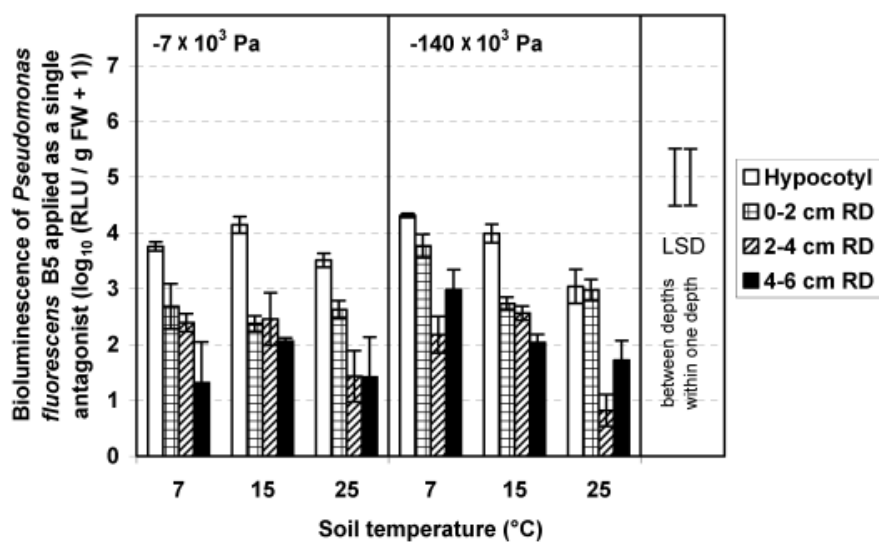

Fig. 6. Combined influences of soil matric potential and soil temperature on bioluminescence of Pseudomonas fluorescens B5 (lux-marked strain L9) on sugar beet seedlings on the hypocotyl and at different root depths (RD). Mean \pm standard error. Single antagonist treatment only; combined inoculum not included in the analysis. FW = plant fresh weight. Temperatures and matric potentials represent means: a diurnal fluctuation of 3 to $5^{\circ} \mathrm{C}$ was observed and soil matric potential measurements ranged from $-5 \times 10^{3}$ and $-10 \times 10^{3} \mathrm{~Pa}$ and from $-120 \times 10^{3}$ and $-180 \times 10^{3} \mathrm{~Pa}$, respectively. Three replicates, each consisting of two plants, were recovered without seed pellet when they started to develop true leaves. The main effects of temperature $(P=0.002)$, root depth $(P<0.001)$, and the interactions between temperature and matric potential $(P=0.046)$, root depth and temperature $(P=0.05)$, and root depth and matric potential $(P=0.044)$ were significant. Correlation between $\log (\mathrm{CFU} / \mathrm{g} \mathrm{FW}+1)$ and $\log ($ relative luminescence units $[\mathrm{RLU}] / \mathrm{g} \mathrm{FW}+1)$ : $y=0.4014 x+0.4398, R^{2}=0.3667, P<0.001$. Least significant difference (LSD) was calculated at $P=0.05$.
Pseudomonas fluorescens B5 significantly increased the number and dry weight of healthy plants at lower temperatures, especially at the 3 to $12^{\circ} \mathrm{C}$ regime (Fig. 7). This was apparent when either the Pseudomonas fluorescens B5 treatment was compared with the control treatment without antagonists or the mixed treatment (containing both Pseudomonas fluorescens B5 and B. subtilis MBI 600) was compared with the treatment containing $B$. subtilis MBI 600 alone (Fig. 7). At intermediate temperatures (10 to 20 and 15 to $25^{\circ} \mathrm{C}$ ), the increase was smaller and mostly not significant. At high temperatures $\left(25\right.$ to $\left.35^{\circ} \mathrm{C}\right)$, emergence was extremely low with no differences between treatments (Fig. 7). The number and dry weight of healthy plants were both significantly increased in the colder temperature regime $\left(3\right.$ to $\left.12^{\circ} \mathrm{C}\right)$ compared with the warmer ones in all treatments including the control treatment without antagonists (Fig. 7). The apparent increase in disease pressure with soil temperature suggested that the differences in antagonistic performance of Pseudomonas fluorescens B5 at different temperature regimes were due to differences in disease pressure rather than to a direct effect of temperature on the antagonist.

Plant survival and dry weight of healthy plants were similar under the 3 to $25^{\circ} \mathrm{C}$ and 15 to $25^{\circ} \mathrm{C}$ regimes, which had the same day temperature, but differed in their diurnal amplitude. In contrast, plant number and dry weight were significantly in-

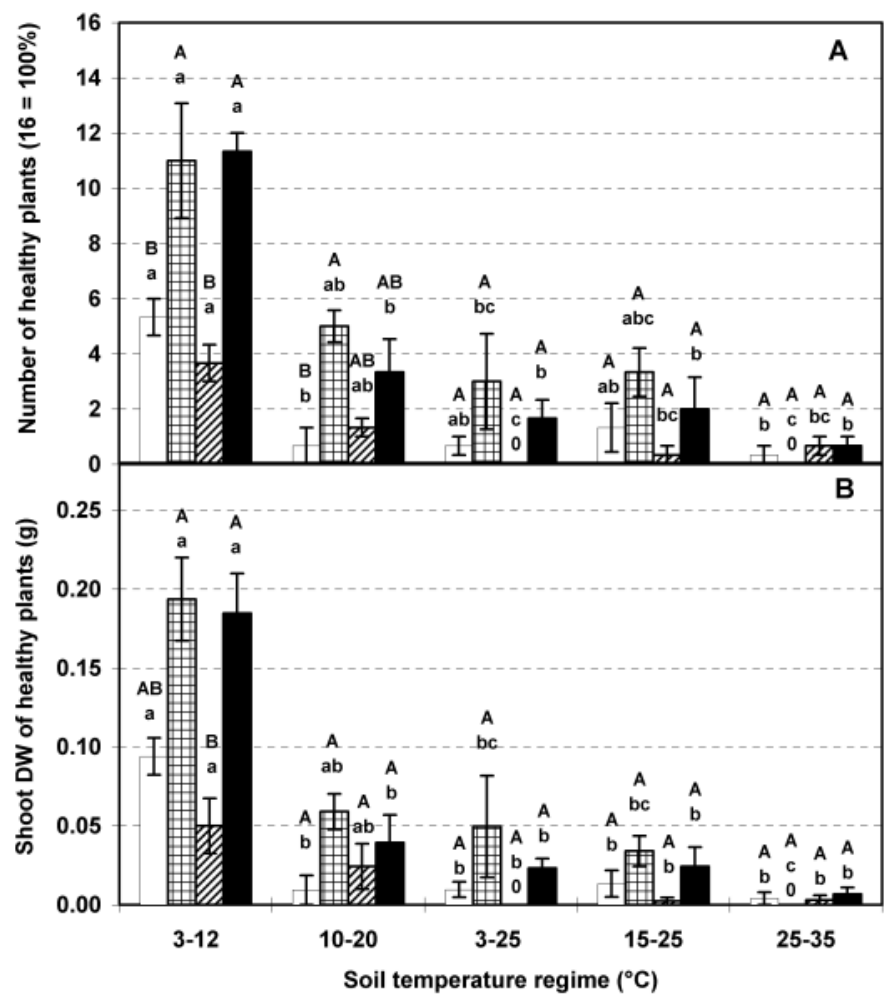

Control $\square P$. fluorescens $\square$ B. subtilis $\square$ Combined treatment

Fig. 7. A, Number and B, shoot dry weight (DW) of healthy sugar beet seedlings as a measure of the effect of different soil temperature regimes on antagonistic activity of Pseudomonas fluorescens B5 and Bacillus subtilis MBI 600 toward Pythium ultimum. Combined treatment: Pseudomonas fluorescens and B. subtilis applied together in a combined inoculum. Three replicate microcosms were set up per treatment with 16 seeds per replicate. For statistical analysis, plant numbers were calculated as percentages, data were arcsine square root-transformed, and plant dry weight data were square root-transformed. Tukey's significant difference test $(P=0.05)$ was performed to compare antagonist treatments within each soil temperature regime (uppercase letters above bars) and for comparison of soil temperature regimes within each antagonist treatment (lowercase letters). Within each soil temperature regime or within each antagonist treatment, bars with the same letters are not significantly different. Significant factor effects are shown in Table 5. 
creased under the 3 to $12^{\circ} \mathrm{C}$ regime, which had the same night temperature as the 3 to $25^{\circ} \mathrm{C}$ regime. They were also slightly increased in the 10 to $20^{\circ} \mathrm{C}$ treatment, which had the same average temperature as the 3 to $25^{\circ} \mathrm{C}$ regime $\left(14\right.$ to $15^{\circ} \mathrm{C}$ ) (Fig. 7 ). This observation was further supported by multiple linear regression analysis. The factors day temperature and Pseudomonas fluorescens, but not the factors night temperature and $B$. subtilis, contributed significantly to the accuracy of the model (Table 6). This indicated that the maximum (day) temperature rather than the minimum (night) or the average temperature in soil was decisive for the development of disease pressure and, subsequently, the observed antagonistic activity of Pseudomonas fluorescens B5.

Influence of soil temperature and matric potential on antagonistic activity against Pythium ultimum. Soil temperature, matric potential, and treatment with Pseudomonas fluorescens B5 significantly affected the number and dry weight of healthy plants

TABLE 5. Influence of soil temperature, soil matric potential, and the applied antagonist inoculum (Pseudomonas fluorescens B5 and Bacillus subtilis MBI 600 ), and the interactions of these factors on the survival of sugar beet seedlings in soil infested with Pythium ultimum (number and dry weight of healthy plants at end of experiment) ${ }^{\mathrm{a}}$

\begin{tabular}{|c|c|c|c|c|}
\hline \multirow{2}{*}{$\begin{array}{l}\text { Factors and factor } \\
\text { interactions }\end{array}$} & \multicolumn{2}{|c|}{$\begin{array}{l}\text { Temperature } \\
\text { regime experiment }\end{array}$} & \multicolumn{2}{|c|}{$\begin{array}{c}\text { Matric potential } \times \\
\text { temperature } \\
\text { experiment }\end{array}$} \\
\hline & Number & Dry weight & Number & Dry weight \\
\hline Temperature & $<0.001$ & $<0.001$ & $<0.001$ & $<0.001$ \\
\hline Matric potential & $\ldots$ & $\ldots$ & $<0.001$ & 0.001 \\
\hline Pseudomonas fluorescens & $<0.001$ & $<0.001$ & $<0.001$ & $<0.001$ \\
\hline B. subtilis & NS & NS & NS & NS \\
\hline $\begin{array}{l}\text { Temperature } \times \text { matric } \\
\text { potential }\end{array}$ & & & NS & NS \\
\hline P. fluorescens $\times$ temperature & 0.014 & NS & NS & NS \\
\hline B. subtilis $\times$ temperature & NS & NS & NS & NS \\
\hline $\begin{array}{l}P \text {. fluorescens } \times \text { matric } \\
\text { potential }\end{array}$ & . & & 0.007 & NS \\
\hline B. subtilis $\times$ matric potential & & & NS & NS \\
\hline$P$. fluorescens $\times B$. subtilis & NS & NS & NS & NS \\
\hline
\end{tabular}

a $P$ values were obtained by three-way analysis of variance (ANOVA) (described in text). In the experiment with different temperature regimes, plant number was calculated as a percentage and data were arcsine square roottransformed; and dry weight data were square root-transformed to achieve normal distributed data; in the temperature $\times$ matric potential experiment, no data transformation was necessary. NS $=$ not significant. There were no significant three-way and four-way interactions. Corresponding data are shown in Figures 7 and 8.

TABLE 6. Linear regression: Shoot dry weight of healthy plants (square root-transformed values) in soil infested with Pythium ultimum as a function of day temperature in soil, night temperature in soil, and bacterial treatment ${ }^{\mathrm{a}}$

\begin{tabular}{lccc}
\hline $\begin{array}{l}\text { Model parameters } \\
\text { included }\end{array}$ & $\begin{array}{c}\text { Significance } \\
(P) \text { of entered } \\
\text { variables }\end{array}$ & $\begin{array}{c}\text { Significance } \\
(P) \text { of whole } \\
\text { model }\end{array}$ & $\begin{array}{c}\text { Square of } \\
\text { correlation } \\
\text { coefficient }\left(R^{2}\right)\end{array}$ \\
\hline Day temperature & $<0.001$ & $<0.001$ & 0.528 \\
Day temperature & $<0.001$ & $<0.001$ & 0.659 \\
Pseudomonas fluorescens & $<0.001$ & $\ldots$ & $\ldots$ \\
Day temperature & $<0.001$ & $<0.001$ & 0.670 \\
Night temperature & 0.176 & $\ldots$ & $\ldots$ \\
Pseudomonas fluorescens & $<0.001$ & $\ldots$ & $\ldots$ \\
Day temperature & $<0.001$ & $<0.001$ & 0.677 \\
Night temperature & 0.175 & $\ldots$ & $\ldots$ \\
Pseudomonas fluorescens & $<0.001$ & $\ldots$ & $\ldots$ \\
Bacillus subtilis & 0.276 & $\ldots$ & $\ldots$ \\
\hline
\end{tabular}

${ }^{a}$ Calculation is based on data presented in Figure 7. Maximum correlation was reached by including the variables day temperature and treatment with Pseudomonas fluorescens: square root (dry weight) $=0.412-0.013$ [day temperature $\left.\left({ }^{\circ} \mathrm{C}\right)\right]+0.1$ (Pseudomonas fluorescens). in soil inoculated with Pythium ultimum $(P<0.001)$ (Fig. 8). No interaction between soil matric potential and temperature was observed. Plant number and dry weight decreased with increasing temperature and matric potential in all treatments including the control without any antagonists (Fig. 8). This indicated an increase in disease pressure with temperature (as observed in the experiment with different temperature regimes) and with increasing soil matric potential. Treatment with Pseudomonas fluorescens B5 (applied either solely or as combined inoculum with $B$. subtilis) always increased plant number and dry weight compared with the treatments without Pseudomonas fluorescens B5 (untreated control or B. subtilis MBI 600 alone) (Fig. 8). An interaction between the factors Pseudomonas fluorescens B5 and matric potential $(P=0.007)$ was observed in the number of healthy plants (Table 5); the antagonistic effect of Pseudomonas fluorescens B5 was more pronounced at the drier matric potential (Fig. $8)$. At conditions least favorable for the fungus $\left(7^{\circ} \mathrm{C},-120 \times\right.$ $10^{3} \mathrm{~Pa}$ ), the treatment with Pseudomonas fluorescens B5 resulted in almost full emergence. However, at conditions most favorable $\left(25^{\circ} \mathrm{C},-7 \times 10^{3} \mathrm{~Pa}\right)$, the effect of the antagonist was small.

There was a significant linear relationship between the number (Table 7) or dry weight of healthy plants (Table 8) and soil temperature, matric potential, and Pseudomonas fluorescens as predictors in a multiple linear regression model. When the three factors were entered stepwise, soil temperature had the highest correlation with number and dry weight of healthy plants and was entered first, followed by Pseudomonas fluorescens and matric potential (Tables 7 and 8). According to the regression equation,

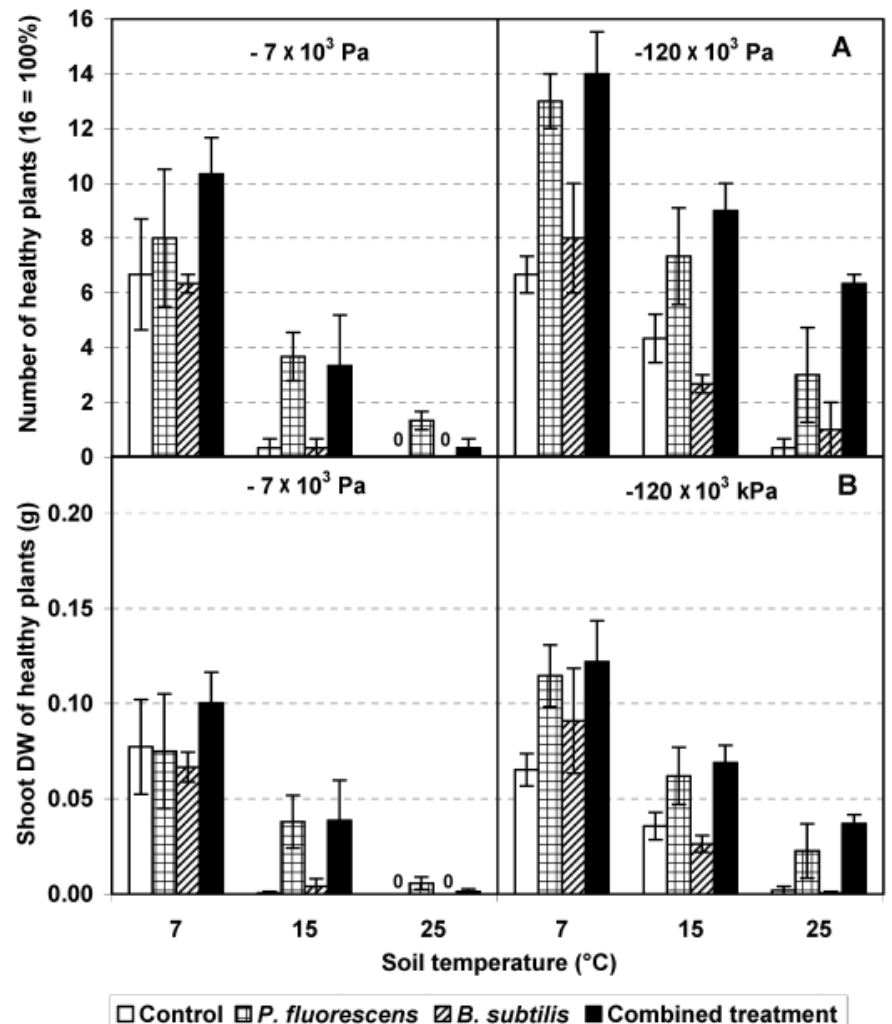

Fig. 8. A, Number and B, shoot dry weight (DW) of healthy sugar beet seedlings as a measure of the combined effects of soil temperature and soil matric potential on antagonistic activity of Pseudomonas fluorescens B5 and Bacillus subtilis MBI 600 toward Pythium ultimum. Combined treatment: Pseudomonas fluorescens and B. subtilis applied together in a combined inoculum. Three replicate microcosms were set up per treatment with 16 seeds per replicate. Plants were recovered when they started to develop true leaves. Temperatures and matric potentials represent means: a diurnal fluctuation of 3 to $5^{\circ} \mathrm{C}$ was observed and soil matric potentials ranged from $-5 \times$ $10^{3}$ and $-10 \times 10^{3} \mathrm{~Pa}$ and from $-70 \times 10^{3}$ and $-150 \times 10^{3} \mathrm{~Pa}$, respectively. Significant factor effects are shown in Table 5 . 
Pseudomonas fluorescens B5 increased the number of plants per microcosm by $3.6(16=100 \%)$ and the plant dry weight by $0.027 \mathrm{~g}$ on average. However, the linear model does not take into account the interaction between the factors Pseudomonas fluorescens and matric potential observed in the number of healthy plants (Table 5). The factor B. subtilis was not significant (Tables 7 and 8).

\section{DISCUSSION}

Pythium infection occurs mainly at high matric potentials (wet soils) and lower temperatures, whereas other damping-off fungi (Aphanomyces, Rhizoctonia) prevail at higher temperatures (34). The increase in disease pressure with matric potential observed is in accordance with previous studies $(14,34,35)$, and $-10 \times 10^{3} \mathrm{~Pa}$ is reported to be optimal for Pythium ultimum $(14,20)$. Contrary to previous observations $(34,35,44)$, we observed an increase in disease incidence with temperature. This discrepancy may be due to differences between isolates, since isolates of the same Pythium species vary in their temperature optimum (40). The observations of Lifshitz and Hancock (31) offer another possible explanation. They found that the temperature optimum for Pythium growth shifted to lower temperatures when the fungus was added to nonsterile instead of sterile soil, indicating a difference between the physiological and ecological optima. In previous studies, inoculum sizes may have been lower and Pythium spp. may have been out-competed by other fungi at higher temperatures in the long run, whereas the massive vegetative inoculum applied in our investigation may have ensured a decisive competitive advantage of Pythium spp., at least over the short observation period of 14 days. The nutrients present in the pea mash inoculum may have delivered an additional competitive advantage to the fungus. Propagule counts of Pythium ultimum were not made in this study, but the very high disease incidence under conditions optimal for the fungus (zero survival of the seedlings in untreated controls) indicates a very high disease pressure. Our conditions thus simulate a worst-case scenario.

Based on this investigation and that of Mathre et al. (35), it is apparent that environmental factors not only affect biocontrol agents directly. The effects of environmental factors on the growth and activity of the pathogen can also determine whether a bacterial agent has a sufficient biological control effect or not. In both studies, treatment with Pseudomonas strains resulted in $100 \%$ emergence only under conditions suboptimal for the fungus. This may be due to reduced activity or an increased vulner-

TABLE 7. Linear regression: Number of healthy plants in soil infested with Pythium ultimum as a function of temperature, matric potential, and bacterial treatment ${ }^{\mathrm{a}}$

\begin{tabular}{lccc}
\hline $\begin{array}{l}\text { Model parameters } \\
\text { included }\end{array}$ & $\begin{array}{c}\text { Significance } \\
(P) \text { of entered } \\
\text { variables }\end{array}$ & $\begin{array}{c}\text { Significance } \\
(P) \text { of whole } \\
\text { model }\end{array}$ & $\begin{array}{c}\text { Square of } \\
\text { correlation } \\
\text { coefficient }\left(R^{2}\right)\end{array}$ \\
\hline Soil temperature & $<0.001$ & $<0.001$ & 0.473 \\
Soil temperature & $<0.001$ & $<0.001$ & 0.637 \\
Pseudomonas fluorescens & $<0.001$ & $\ldots$ & $\ldots$ \\
Soil temperature & $<0.001$ & $<0.001$ & 0.743 \\
Pseudomonas fluorescens & $<0.001$ & $\ldots$ & $\ldots$ \\
Matric potential & $<0.001$ & $\ldots$ & $\ldots$ \\
Soil temperature & $<0.001$ & $<0.001$ & 0.747 \\
Pseudomonas fluorescens & $<0.001$ & $\ldots$ & $\ldots$ \\
Matric potential & $<0.001$ & $\ldots$ & $\ldots$ \\
Bacillus subtilis & 0.313 & $\ldots$ & $\ldots$ \\
\hline
\end{tabular}

a Calculation is based on data presented in Figure 8 (three replicates). Maximum correlation was reached by including the variables temperature, treatment with Pseudomonas fluorescens, and matric potential: number of healthy plants $=7.966-0.414$ [soil temperature $\left.\left({ }^{\circ} \mathrm{C}\right)\right]+$ 3.554 (Pseudomonas fluorescens) - $2.518 \times 10^{-2}$ [matric potential $\left.\left(\times 10^{3} \mathrm{~Pa}\right)\right]$. ability of the pathogen to the biocontrol agent under less favorable conditions.

At very high temperatures $\left(25\right.$ to $\left.35^{\circ} \mathrm{C}\right)$, reduced root colonization by Pseudomonas fluorescens offers an additional explanation for the absence of antagonistic activity. The concentration of 2,4-diacetylphloroglucinol (an antibiotic with antifungal activity) detected in the rhizosphere (3) and the biocontrol activity against Gaeumannomyces graminis (6) were proportional to the population density of the introduced Pseudomonas fluorescens inoculum. Furthermore, the lower in situ bioluminescence measured at higher temperatures $\left(24\right.$ to $\left.27^{\circ} \mathrm{C}\right)$ in this study indicated that the reduced population size of Pseudomonas fluorescens at higher temperatures also was matched by a lower physiological activity.

However, the differences in colonization observed at different matric potentials and soil temperatures do not explain all the observed differences in biocontrol efficiency against Pythium ultimum. At low temperatures, biocontrol efficacy of Pseudomonas fluorescens was increased, despite decreased colonization down the root. Mathre et al. (35) obtained similar results in sweet corn. There, biocontrol activity of Pseudomonas aureofaciens against Pythium damping-off was not reduced at temperatures below $15^{\circ} \mathrm{C}$. However, the population size was 2 orders of magnitude lower than at temperatures above $15^{\circ} \mathrm{C}$ because the antagonist did not multiply on the seed surface at low temperatures. Thus, population size and growth alone are not sufficient predictors of biocontrol activity. Production of compounds important for biological control may be affected by temperature independently from growth. Antibiotics and siderophores were the decisive factor for biological control of Pythium by Pseudomonas fluorescens B5 (51). In in vitro investigations, temperature affected the production of both compounds in several strains of Pseudomonas fluorescens $(3,16,53)$; temperatures above $30^{\circ} \mathrm{C}$ mostly had a negative effect $(16,55)$. In situ production of active compounds is likely to be affected by temperature in the same way, resulting in different degrees of biocontrol efficiency even if population sizes are similar.

Several authors have found decreased survival of pseudomonads at temperatures above 20 to $24^{\circ} \mathrm{C}$ on roots $(5,32$, this study), in soil (19), and on dry surfaces (36). However, there are also reports of increased rhizosphere colonization by pseudomonads at $22^{\circ} \mathrm{C}(8,48)$, and there is evidence that different strains and species of Pseudomonas display different optima for rhizosphere colonization for both temperature (52) and matric potential $(23,30,32,34,43)$.

TABLE 8. Linear regression: Shoot dry weight of healthy plants in soil infested with Pythium ultimum as a function of temperature, matric potential, and bacterial treatment

\begin{tabular}{lccc}
\hline $\begin{array}{l}\text { Model parameters } \\
\text { included }\end{array}$ & $\begin{array}{c}\text { Significance } \\
(P) \text { of entered } \\
\text { variables }\end{array}$ & $\begin{array}{c}\text { Significance } \\
(P) \text { of whole } \\
\text { model }\end{array}$ & $\begin{array}{c}\text { Square of } \\
\text { correlation } \\
\text { coefficient }\left(R^{2}\right)\end{array}$ \\
\hline Soil temperature & $<0.001$ & $<0.001$ & 0.555 \\
Soil temperature & $<0.001$ & $<0.001$ & 0.639 \\
Pseudomonas fluorescens & $<0.001$ & $\ldots$ & $\ldots$ \\
Soil temperature & $<0.001$ & $<0.001$ & 0.701 \\
Pseudomonas fluorescens & $<0.001$ & $\ldots$ & $\ldots$ \\
Matric potential & 0.001 & $\ldots$ & $\ldots$ \\
Soil temperature & $<0.001$ & $<0.001$ & 0.703 \\
Pseudomonas fluorescens & $<0.001$ & $\ldots$ & $\ldots$ \\
Matric potential & $<0.001$ & $\ldots$ & $\ldots$ \\
Bacillus subtilis & 0.424 & $\ldots$ & $\ldots$ \\
\hline
\end{tabular}

a Calculation is based on data presented in Figure 8 (three replicates). Maximum correlation was reached with the variables temperature, treatment with Pseudomonas fluorescens, and matric potential: shoot dry weight of healthy plants $(\mathrm{g})=8.882 \times 10^{-2}-4.387 \times 10^{-3}$ [soil temperature $\left.\left({ }^{\circ} \mathrm{C}\right)\right]+$ $2.619 \times 10^{-2}$ (Pseudomonas fluorescens) $-1.719 \times 10^{-4}[$ (matric potential $\left.\left(\times 10^{3} \mathrm{~Pa}\right)\right]$. 
At intermediate matric potentials ranging from $-70 \times 10^{3}$ to $-140 \times 10^{3} \mathrm{~Pa}$, rhizosphere populations of Pseudomonas fluorescens reached maximum levels in this study and in other studies $(19,23,41,43)$. This may be due to the reduced accessibility of the bacteria to protozoan predators (57). At such potentials, larger pores are dry, restricting the movement of protozoa while bacteria are inaccessible in pores with a diameter of $\leq 2 \mu \mathrm{m}$, which are still water-filled (43). Another reason may be increased root exudation (4).

Population densities of Pseudomonas fluorescens B5 were equal at $-7 \times 10^{3} \mathrm{~Pa}$ and $-140 \times 10^{3} \mathrm{~Pa}$ when calculated per unit fresh weight of root or hypocotyl, but the total population size was higher at $-140 \times 10^{3} \mathrm{~Pa}$ than at $-7 \times 10^{3} \mathrm{~Pa}$. Methodological difficulties are the probable reason for this discrepancy. Under dry conditions, a larger amount of soil generally adheres to roots, probably due to increased root exudation (4), leading to higher sample fresh weights. Parke et al. (42) found that populations of Pseudomonas fluorescens PRA25rif used as a seed treatment were closely associated with or in very close vicinity to the root. Recovering increasing amounts of adhering rhizosphere soil brought no increase in the recovered population size and consequently resulted in a decreased population size per gram of sample. The strain used in this study (Pseudomonas fluorescens B5) also appeared to be closely confined to the rhizosphere since no movement between root systems of adjacent plants was detected (unpublished data). Thus, although an increased population of Pseudomonas fluorescens B5 was present per plant at $-140 \times$ $10^{3} \mathrm{~Pa}$ compared with $-7 \times 10^{3} \mathrm{~Pa}$, we obtained equal population densities in the different root sections, which were calculated per gram of root fresh weight. The same effect may also explain why we found significantly lower population sizes per gram of root fresh weight of $B$. subtilis MBI 600 at $-140 \times 10^{3} \mathrm{~Pa}$, whereas the total population size per plant was not influenced by matric potential. The population consisted mainly of inactive spores, which should not be affected by soil dryness.

This is the likely explanation for the observed lack of biocontrol activity of the strain observed in this study and in another study (17). It also explains why rhizosphere populations of $B$. subtilis were generally less affected by soil parameters. In this as well as in other studies $(18,26), B$. subtilis was mainly detected in the sections adjacent to the treated seed (hypocotyl and upper root section). That suggests that it may merely have been restricted to the point of inoculation not actively spreading along the root.

Numerous authors have reported a decrease in the population size of seed inoculants with root depth $(1,23,30,46,58)$, the extent of which depended on the prevailing conditions and the bacterial strains used. The influence of percolating water was an undesired limitation in interpreting early studies on matric potential, because high matric potentials needed to be maintained by watering from the top, whereas watering was not always necessary at lower matric potentials. The influence of percolating water, rather than the matric potential itself, was responsible for increased movement down the root at higher matric potentials (43). In subsequent studies $(23,30)$, water losses were replenished from a reservoir at the bottom, eliminating the possibility of percolation, but not of upward flow. Furthermore, this method is only feasible at high matric potentials. In this study, water losses were measured at three depths and replenished by appropriately small injections in 10 different positions to avoid percolation and minimize mass flow. However, as water had to spread from the injection points, localized flow could not be completely avoided and there was a possibility of thermally driven flow (caused by temperature gradients within the microcosms), although this was reduced to a minimum in the constant temperature regimes. Colonization down the root by Pseudomonas fluorescens was greater than in other studies carried out in the absence of percolating water $(5,23,30)$. However, since rhizosphere populations of the co-inoculated
B. subtilis were largely confined to the upper part of the roots, water movement could only play a very limited role in any spread of the bacterial inocula. Furthermore, downward colonization of Pseudomonas fluorescens was not reduced even under dry soil conditions $\left(-140 \times 10^{3} \mathrm{~Pa}\right)$ where large water-filled pores $(>2 \mu \mathrm{m})$ can be excluded as channels for water movement except in the immediate vicinity of the points of injection. Thus, water movement is unlikely to account for the downward movement of Pseudomonas fluorescens. Bacterial transport by vectors (nematodes and fungal hyphae) or near the root tip $(4,23)$ offers a possible explanation. Rhizosphere-colonizing bacteria also may move in the water film at the root surface $(2,4,24)$. Diurnal shrinking and swelling of roots can create movement of this water film at the root-soil interface $(12,24)$, which could facilitate passive dispersal of rhizobacteria along the root, although this seems less probable at the lower potentials.

In the strain of Pseudomonas fluorescens used, bioluminescence was strongly correlated with dehydrogenase activity in in vitro cultures and is thus a good measure for physiological activity. However, high cell numbers $\left(>10^{4} \mathrm{CFU} / \mathrm{cm}\right.$ of root) were necessary to detect measurable levels of in situ bioluminescence in this and other studies $(39,46,54)$. Although the sensitivity of this technique can be increased two to severalfold by the addition of nutrients to the sample before measurement (37-39), our aim was to measure the actual activity under particular environmental conditions and not the potential activity.

In conclusion, soil temperature was a limiting factor for the biocontrol performance of Pseudomonas fluorescens B5. To ensure sufficient biological control of this strain, it is necessary to complement it with another strain with a higher temperature optimum. Pseudomonas aureofaciens AB254 (35) and the fungal antagonist Pythium nunn (44) showed good biological control against Pythium ultimum at temperatures above $22^{\circ} \mathrm{C}$. These strains may therefore complement Pseudomonas fluorescens B5 in a combined inoculum, although compatibility would have to be confirmed.

\section{ACKNOWLEDGMENTS}

This study has been carried out with financial support from the Commission of the European Communities, Agriculture and Fisheries (FAIR), specific RTD programme CT 96 1373, "Improvement of biological seed treatments against damping-off in crop production." It does not necessarily reflect its views and in no way anticipates the Commission's future policy in this area. We thank R. Shiel (University of Newcastle) and I. Wilson (University of Aberdeen) for valuable advice on the statistical evaluation of the data, U. Fischer and R. Tilcher from KWS SAAT AG (Einbeck, Germany) for advice and supply of sugar beet seeds, and G. A. Wolf (University of Göttingen) and P. Fiddaman (Microbio Ltd., Hempstead, UK) for the supply of the bacterial strains.

\section{LITERATURE CITED}

1. Bahme, J. B., and Schroth, M. N. 1987. Spatial temporal colonization pattern of a rhizobacterium on underground organs of potato. Phytopathology 77:1093-1100.

2. Bandoni, R. J., and Koske, R. E. 1974. Monolayers and microbial dispersal. Science 183:1079-1080.

3. Bonsall, R. F., Weller, D. M., and Thomashow, L. S. 1997. Quantification of 2,4-diacetyl-phloroglucinol produced by fluorescent Pseudomonas spp. in vitro and in the rhizosphere of wheat. Appl. Environ. Microbiol. 63:951-955.

4. Bowen, G. D., and Rovira, A. D. 1976. Microbial colonization of plant roots. Annu. Rev. Phytopathol. 14:121-144.

5. Bowers, J. H., and Parke, L. 1993. Colonization of pea (Pisum sativum 1.) taproots by Pseudomonas fluorescens: Effect of soil temperature and bacterial motility. Soil Biol. Biochem. 25:1693-1701.

6. Bull, C. T., Weller, D. M., and Thomashow, L. S. 1991. Relationship between root colonization and suppression of Gaeumannomyces graminis var. triticii by Pseudomonas fluorescens strain 2-79. Phytopathology 81:954-958. 
7. Capper, A. L., and Higgins, K. P. 1993. Application of Pseudomonas fluorescens isolates to wheat as potential biocontrol agents against takeall. Plant Pathol. 42:560-567.

8. Davies, K. G., and Whitbread, R. 1989. Factors affecting the colonization of a root system by fluorescent pseudomonads: The effects of water, temperature and soil microflora. Plant Soil 116:247-256.

9. De Lorenzo, V., Herrero, M., Jakubzik, U., and Timmis, K. N. 1990. Mini-Tn5 transposon derivatives for insertion mutagenesis, promoter probing, and chromosomal insertion of cloned DNA in Gram-negative eubacteria. J. Bacteriol. 172:6568-6572.

10. Duffy, B. K., and Weller, D. M. 1995. Use of Gaeumannomyces graminis var. graminis alone and in combination with fluorescent Pseudomonas spp. to suppress take all in wheat. Plant Dis. 79:907-911.

11. Elad, Y. 1990. Reasons for the delay in biological control in development of biological control of foliar pathogens. Phytoparasitica 18:99105.

12. Faiz, S. M. A., and Weatherly, P. E. 1982. Root contraction in transpiring plants. New Phytol. 92:333-343.

13. Fiddaman, P. J., and Rossall, S. 1994. The production of antifungal volatiles by Bacillus subtilis. J. Appl. Bacteriol. 74:119-126.

14. Fukui, R., Campbell, G. S., and Cook, J. 1994. Factors influencing the incidence of embryo infection by Pythium spp. during germination of wheat seeds in soils. Phytopathology 84:695-702.

15. Fukui, R., Poinar, E. I., Bauer, P. H., Schroth, M. N., Hendson, M., Wang, X.-L., and Hancock, J. G. 1994. Spatial colonization patterns and interactions of bacteria on inoculated sugar beet seed. Phytopathology 84:1338-1345.

16. Garibaldi, J. A. 1971. Influence of temperature on iron metabolism of a fluorescent pseudomonad. J. Bacteriol. 105:1036-1038.

17. Georgakopoulos, D. G., Fiddaman, P., Leifert, C., and Malathracis, N. E. 2002. Biological control of cucumber and sugar beet damping-off caused by Pythium ultimum with bacterial and fungal antagonists. J. Appl. Microbiol. 92:1078-1086.

18. Halverson, L. J., Clayton, M. K., and Handelsman, J. 1993. Population biology of Bacillus cereus UW85 in the rhizosphere of field-grown soybeans. Soil Biol. Biochem. 25:485-493.

19. Hartel, P. G., Fuhrmann, J. J., Johnson, W. F., Lawrence, E. G., Loez, C. S., Mullen, M. D., Skipper, H. D., Staley, T. E., Wolf, D. C., Wollum, A. G., II, and Zuberer, D. A. 1994. Survival of a LacZY-containing Pseudomonas putida strain under stressful abiotic soil conditions. Soil Sci. Soc. Am. J. 58:770-776.

20. Hering, T. F., Cook, R. J., and Tang, W. H. 1987. Infection of wheat embryos by Pythium species during seed germination and the influence of seed age and soil matric potential. Phytopathology 77:1104-1108.

21. Heupel, M. 1992. Biologische Bekämpfung bodenbürtiger Wurzelbranderreger der Zuckerrübe (Beta vulgaris L. ssp. vulgaris var. altissima DOELL) durch den Einsatz mikrobieller Antagonisten. Ph.D. thesis. University of Göttingen.

22. Howell, D. C. 1997. Statistical Methods for Psychology. 4th ed. Belmont, Duxbury, CA.

23. Howie, W. J., Cook, R. J., and Weller, D. M. 1987. Effects of soil matric potential and cell motility on wheat root colonization by fluorescent Pseudomonas suppressive to take-all. Phytopathology 77:286-292.

24. Huck, M. G., Klepper, B., and Taylor, H. M. 1970. Diurnal variations in root diameter. Plant Physiol. 45:529-530.

25. Killham, K. S., and Yeomans, C. V. 2001. Rhizosphere carbon flow measurement and implications: From isotopes to reporter genes. Plant Soil 232:91-96.

26. Kim, D.-S., Weller, D. M., and Cook, R. J. 1997. Population dynamics of Bacillus sp. L324-92 $\mathrm{R}_{12}$ and Pseudomonas fluorescens $2-79 \mathrm{RN}_{10}$ in the rhizosphere of wheat. Phytopathology 87:559-564.

27. Kinnear, P. R., and Gray, C. D. 1999. SPSS for Windows Made Simple. 3rd ed. Psychology Press, East Sussex, UK.

28. Knox, O. G. G. 2000. Exploiting nitrate respiration to optimise antagonistic control of root disease in soil. Ph.D. thesis. University of Aberdeen, UK.

29. Knox, O. G. G., Killham, K., and Leifert, C. 2002. The reliability of marker/reporter genes in bio-control studies with Bacillus subtilis. Biocontrol Sci. Technol. 12:637-641.

30. Liddell, C. M., and Parke, J. L. 1989. Enhanced colonization of pea taproots by a fluorescent pseudomonad biocontrol agent by water infiltration into soil. Phytopathology 79:1327-1332.

31. Lifshitz, R., and Hancock, J. G. 1983. Saprophytic development of Pythium ultimum in soil as a function of water matric potential and temperature. Phytopathology 73:257-261.

32. Loper, J. E., Haack, C. A., and Schroth, M. N. 1985. Population dynamics of soil pseudomonads in the rhizosphere of potato (Solanum tuberosum L.). Appl. Environ. Microbiol. 49:416-422.

33. Marshall, T. J., Holmes, J. W., and Rose, C. W. 1996. Soil Physics. 3rd ed. Cambridge University Press, Cambridge.
34. Martin, F. N., and Loper, J. E. 1999. Soilborne diseases caused by Pythium spp.: Ecology, epidemiology and prospects for biological control. Crit. Rev. Plant Sci. 18:111-181.

35. Mathre, D. E., Callan, N. W., Johnston, R. H., Miller, J. B., and Schwend, A. 1994. Factors influencing the control of Pythium ultimum-induced seed decay by seed treatment with Pseudomonas aureofaciens AB254. Crop Prot. 13:301-307.

36. Mc Eldowney, S., and Fletcher, M. 1988. The effect of temperature and relative humidity on the survival of bacteria attached to dry solid surfaces. Lett. Appl. Microbiol. 7:83-86.

37. Meikle, A., Amin-Hanjani, S., Glover, L. A., Killham, K., and Prosser, J. I. 1995. Matric potential and the survival and activity of a Pseudomonas fluorescens inoculum in soil. Soil Biol. Biochem. 27:881-892.

38. Meikle, A., Glover, L. A., Killham, K., and Prosser, J. I. 1994. Potential luminescence as an indicator of activation of genetically-modified Pseudomonas fluorescens in liquid culture and in soil. Soil Biol. Biochem. 26:747-755.

39. Meikle, A., Killham, K., Prosser, J. I., and Glower, L. A. 1992. Luminometric measurement of population activity of genetically modified Pseudomonas fluorescens. FEMS Microbiol. Lett. 99:217-220.

40. Nelson, E. B., and Craft, C. M. 1991. Identification and comparative pathogenicity of Pythium spp. from roots and crowns of turfgrasses exhibiting symptoms of root rot. Phytopathology 81:1529-1536.

41. Normander, B., Hendriksen, N. B., and Nybroe, O. 1999. Green Fluorescent protein marked Pseudomonas fluorescens: Localization, viability and activity in the natural barley rhizosphere. Appl. Environ. Microbiol. 65:4646-4651.

42. Parke, J. L., Liddell, C. M., and Clayton, M. K. 1990. Relationship between soil mass adhering to pea taproots and recovery of Pseudomonas fluorescens from the rhizosphere. Soil Biol. Biochem. 22: 495-499.

43. Parke, J. L., Moen, R., Rovira, A. D., and Bowen, G. D. 1986. Soil water flow affects the rhizosphere distribution of a seedborne biocontrol agent, Pseudomonas fluorescens. Soil Biol. Biochem. 18:583-588.

44. Paulitz, T. C., and Baker, R. 1987. Biological control of Pythium damping-off in cucumbers with Pythium nunn: Influence of soil environment and organic amendments. Phytopathology 77:341-346.

45. Pierson, E. A., and Weller, D. M. 1994. Use of mixtures of fluorescent pseudomonads to suppress take all and improve the growth of wheat. Phytopathology 84:940-947.

46. Ramos, C., Molina, L., Mølbak, L., Ramos, J. L., and Molin, S. 2000. A bioluminescent derivative of Pseudomonas putida KT2440 for deliberate release into the environment. FEMS Microbiol. Ecol. 34: 91-102.

47. Rattray, E. A. S., Prosser, J. I., Killham, K., and Glover, L. A. 1990. Luminescence based non-extractive technique for in-situ detection of Escherichia coli in soil. Appl. Environ. Microbiol. 56:3368-3374.

48. Rattray, E. A. S., Tyrrell, J. A., Prosser, J. I., Glover, L. A., and Killham, K. 1993. Effect of soil bulk density and temperature on wheat rhizosphere colonization. Eur. J. Soil Biol. 29:73-82.

49. Russell, C. N. 1996. Lux gene reporting of the interaction between Gaeumannomyces graminis and an antagonistic pseudomonad in the wheat rhizosphere. Ph.D. thesis. University of Aberdeen, UK.

50. Schippers, B., Bakker, A. W., and Baker, P. A. H. M. 1987. Interactions of deleterious and beneficial rhizosphere organisms and the effect of cropping practices. Annu. Rev. Phytopathol. 25:339-358.

51. Schulz, D., and Wolf, G. A. 2002. Influence of motility, adhesion and the production of siderophores and antibiotics of Ps. fluorescens B5 and Ps. corrugata R117 on rhizosphere colonization and biocontrol in microcosm. Mitt. Biol. Bundesforsch. Landwirt. Forsch. 390394.

52. Seong, K.-Y., Hofte, M., Boelens, J., and Verstraete, J. 1991. Growth, survival, and root colonization of plant growth beneficial Pseudomonas fluorescens ANPP15 and Pseudomonas aeruginosa 7NSK2 at different temperatures. Soil Biol. Biochem. 23:423-428.

53. Shanahan, P., Borro, A., Ogara, F., and Glennon, J. D. 1992. Isolation of 2,4-diacetylphloroglucinol from a fluorescent pseudomonad and investigation of physiological parameters influencing its production. Appl. Environ. Microbiol. 58:353-358.

54. Shaw, J. J., Dane, F., Geiger, D., and Kloepper, J. W. 1992. Use of bioluminescence for the detection of genetically engineered microorganisms released into the environment. Appl. Environ. Microbiol. 58:267-273.

55. Slininger, P. J., and Shea-Wilbur, M. A. 1995. Liquid-culture pH, temperature and carbon (not nitrogen) source regulate phenazine productivity of the take-all biocontrol agent Pseudomonas fluorescens 2-79. Appl. Microbiol. Biotechnol. 43:794-800.

56. Suslow, T. V., and Schroth, M. N. 1982. Rhizobacteria in sugar beets: Effects of seed application and root colonization on yield. Phytopathology 72:199-206. 
57. Thirup, L., Ekelund, F., Johnson, K., and Jacobsen, C. S. 2000. Population dynamics of the fast-growing sub-population of Pseudomonas and total bacteria, and their protozoan grazers, revealed by fenpropimorph treatment. Soil Biol. Biochem. 32:1615-1623.

58. Trevors, J. T., van Elsas, J. D., van Overbeek, L. S., and Starodub, M. E. 1990. Transport of a genetically engineered Pseudomonas fluorescens strain through a soil microcosm. Appl. Environ. Microbiol.
56:401-408.

59. Weller, D. M. 1988. Biological control of soilborne pathogens in the rhizosphere with bacteria. Annu. Rev. Phytopathol. 73:15481553.

60. White, D., Leifert, C., Ryder, M. H., and Killham, K. 1996. Lux gene technology - A strategy to optimize biological control of soilborne diseases. New Phytol. 133:173-181. 